\title{
Nonlinearity in Nexus between Working Hours and Productivity
}

\author{
Dongyeol Lee* \\ Hyunjoon Lim**
}

The views expressed herein are those of authors and do not necessarily reflect the official views of the Bank of Korea. When reporting or citing this paper, the authors' name should always be explicitly stated.

\footnotetext{
* Bank of Korea, 39 Namdaemunno, Jung-Gu, Seoul 110-794, Korea. Email: dylee@bok.or.kr ** Bank of Korea, 39 Namdaemunno, Jung-Gu, Seoul 110-794, Korea. Email: limhj1@bok.or.kr
}

We thank Yongsung Chang, Woon Gyu Choi, Kwang Myoung Hwang, Sunyoung Jung, Byoung-Ki Kim, Hyun Jeong Kim, Tae-Jeong Kim and seminar participants at the Bank of Korea and Asia-Pacific Economic Association Annual Conference for their helpful comments and suggestions. 


\section{Contents}

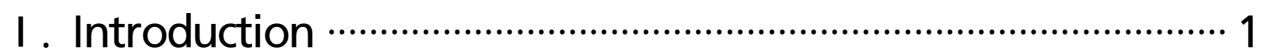

II. Working Hours and Productivity: Theoretical Background $\cdots 5$

III. Working Hours and Productivity: Empirical Analysis ….... 15

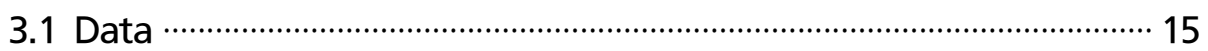

3.2 Cobb-Douglas production function ………………............................... 16

3.3 Translog production function …………………………………….... 23

IV. Concluding Remarks ……………………………………..... 29

Appendix: Industry Classification ……………………………..... 32

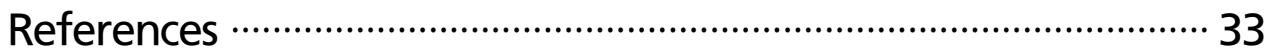




\section{Nonlinearity in Nexus between Working Hours and Productivity}

Average weekly working hours in most industrialized economies have displayed steady declines since the 1970s. Changes in working hours may have two contrasting effects on hourly productivity: a "fatigue effect" and a "learning effect." An increase in working hours may lead to the accumulation of a worker's proficiency and skill in his or her job, while it may at the same time cause the level of the worker's fatigue to increase. Estimation of the Cobb-Douglas and translog production functions with Hansen's (1999) threshold regression methods shows that there exist multiple (at most four) thresholds in the linkage between working time and productivity, supporting the existence of a learning effect as well as a fatigue effect from an extension in working hours. The results of our study provide some implications for the recent discussion on reform of the working time system: (i) a reduction in working hours, on one hand, may increase productivity by reducing fatigue and allowing more leisure, but on the other hand, it may hinder workers from accumulating proficiency and skills, thereby reducing their productivity; (ii) the overall effects of changes in working time depend upon a variety of factors, such as the initial level of working hours and the features of the industry concerned.

Keywords: Working hours, Productivity, Fatigue effect, Learning effect, Threshold regression

JEL Classification: J24, D24, D92, O47 


\section{I . Introduction}

In most industrialized economies, average weekly working hours have displayed steady declines since the 1970s.1) In particular, while some European countries have reduced the working hours dramatically, they have at the same time seen sustained growth. In many industrialized economies, meanwhile, the employment basis has shifted from full-time to flexible and part-time employment in efforts not only to cope with expected decreases in labor forces, resulting mainly from population aging, but also to boost their domestic demands by promoting households' purchasing power. ${ }^{2)}$ It is also expected that this trend toward flexible job programs will spread widely particularly in advanced countries in the future.

Although there is no doubt intuitively that shorter working hours will reduce the level of output per worker, it is far from certain in which direction they will affect his or her hourly productivity. Therefore, in order for a reduction in working hours to be coupled with sustained growth, its positive effects should

\section{Figure 1. Average Weekly Working Hours}
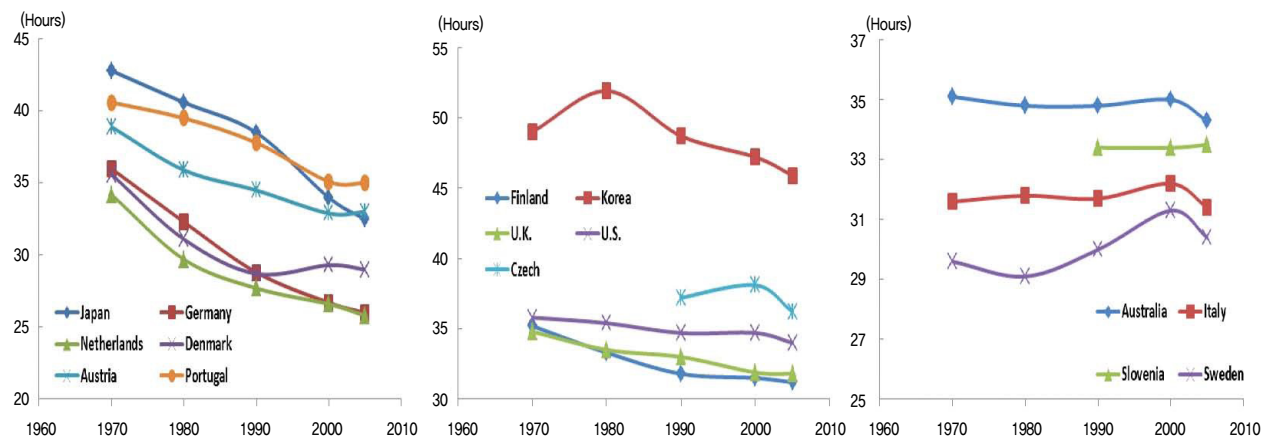

Note: The data relate to total industry. The data on Czech Republic and Slovenia begin in 1995, and those of the U.S. begin in 1977.

Source: EU KLEMS database

1) We considered a year as 52 weeks in calculating the average weekly working hours (i.e., average weekly working hours $=$ total working hours/52 weeks).

2) Among the causes of the reduction in the average working hours is the change in the labor supply: improvement of home technology since the 1970s, e.g., the spread of refrigerators, washing machines, and vacuum cleaners, encouraged more women to enter the work force, thereby increasing total hours while reducing average hours. 
outweigh its adverse ones. That is, the reduction in working hours should boost workers' productivity to an extent sufficient to create new job openings through the substitution between intensive and extensive margins over the longer term.

However, there are still fairly unsubstantiated concerns that shorter working hours may boil down to a reduction in output, notwithstanding the popular belief that it will help workers to be more productive through better quality of life. For instance, it is likely that shorter working hours may hinder workers from concentrating sufficiently on their jobs and accumulating the related skills, thereby reducing their productivity. Besides this, some economists argue that a decline in hours worked may not boost workers' productivity as much as it rather increases labor costs,3) and it may also not be followed by the creation of additional employment-the very opposite to what is initially intended (e.g., Hart 1984; Hoel 1987; Andersen 1987; Huang et al. 2002). In such a case, a decline in working hours will have the adverse effect of slowing growth down. Recent studies have generally concluded that the link between working hours and workers' productivity is an important factor in determining whether a shorter working time expands employment (Hart and McGregor 1988; Huang et al. 2002). Unless reductions in working hours can induce workers to make greater efforts and increase their efficiency, it will be very uncertain whether a working-hour reduction program can reduce unemployment.

Moreover, in the longer term, the effect that shorter working hours have on employment through higher productivity will expand. Ultimately, a critical issue in assessing the validity and relevance of such policy measures will be what effects the shortening of working hours will have on workers' labor productivity.

In this vein, the impact of shorter working hours on labor productivity has been a hotly debated issue for policymakers and economists. However, despite such sharp debate on the macroeconomic impact of changes in working hours, it seems that few are known concerning exactly how, or through which channels, changes in working hours influence productivity (Kelly et al. 2008). A large number of recent studies obtain empirical evidence supporting the argument that the rising

3) The presence of a fixed amount of time, required for workers to prepare their workplaces in order or to become familiar with instruction, may lead to increasing returns to working hours. 
hourly productivity could be accounted for in part by the cuts in working hours (Malinvaud 1973; Leslie and White 1980; Gust and Marquez 2000; McGuckin and Van Ark 2005; Bourlès and Cette 2005, 2007; Dew-Becker and Gordon 2008; Cette et al. 2011).4) Some have, however, shown opposing results (Hart and McGregor 1988; Cueva and Heyer 1998). In addition, Anxo and Bigsten (1989), in estimation of the Swedish manufacturing sector, obtain an elasticity of output to working hours which is equal to 0.9. However, they conclude that, since the estimates are not significantly different from 1 , a reduction in working hours will not exert any significant impact on labor productivity. Rubin and Richardson (1997) report that productivity gains by reductions in working hours tend to decrease as the length of working time diminishes, which implies that the higher the level of the present working hours is, the larger the potential gains will be. In particular, Cette et al. (2011) hypothesize that the presence of a fatigue effect should cause the returns to working hours to decrease at a greater rate above a certain threshold. They also find that the elasticity of hourly productivity with respect to working time is negative and decreasing, but that the statistical significance of the elasticity coefficient is not very high, which in part supports the existence of the fatigue effect with only very weak evidence. Nevertheless, these results do not seem to confirm that shorter working time cannot possibly boost the labor productivity in case of some firms. Rather, what is really revealed is that initial level of working hours may play a crucial role for the extent of productivity gains, and that these gains are not likely to be distributed uniformly across all firms (Anxo 1998). We suspect that the failure to obtain clear results in the previous studies of the nexus between productivity and working hours may be attributable to the possibility that there is a nonlinear relationship between the two variables. In fact, most existing studies that explore the dependence of hourly productivity on working hours have

4) In previous attempts to examine the impacts of changes in working hours on labor productivity, Feldstein (1967), Craine (1973), Leslie (1984) and Shapiro (1986) found that the elasticity of output with regard to working hours stood substantially above 1 , implying that shorter working hours would lessen labor productivity. However, it is not plausible that the output-the hours elasticity is larger than the output-the employment elasticity. If that were the case, firms might have incentives to reduce employment and, instead, increase working hours. This problem may have occurred due to some measurement errors (Estevão 1996). 
focused only on the relationship between the "fatigue effect" and "fixed cost." With such a focus, it is not feasible to generate an environment in which a nonlinear relationship between them exists. We, therefore, find it necessary to introduce a new channel, through which the change in working time can affect productivity: an increase in working hours contributes to improving worker's productivity since substantial time and effort are required to become sufficiently skilled at a certain job.

To this end, we introduce the concept of "learning curves" or "learning at the workplace" - which was first described in the field of psychology and is now widespread and important in fields of economics such as growth, human capital, corporate strategy, etc. - to account for the link between hourly productivity and working hours.5) This concept, which will be called the "learning effect" hereafter, provides us with the very useful implication that excessively short working hours may not be sufficient for workers to become proficient in their jobs. That is, workers' productivity can go up only when their working hours are maintained at least above a minimum level. We show, in consequence, that, as the relative influence of each channel changes over the average level of working hours, the magnitude of productivity elasticity with respect to working hours can vary.

From the methodological perspective, we attempt to find nonlinearity of the relationship between working hours and labor productivity, using industry-level panel data, and thereby exploring some thresholds across average working hours. In its empirical estimation, we employ two types of production functions: the Cobb-Douglas function and the translog function.

To the best of our knowledge, this is the first paper that introduces the learning effect and then tests nonlinearity to explore the link between productivity and working hours. We expect that our attempt will help to explain the remaining puzzles concerning this topic. The remainder of this paper is organized as follows. In Section 2, we introduce the theoretical background and lay out some hypotheses as to the relationship between working hours and hourly productivity,

5) "Learning curves" were first observed by Hermann Ebbinghaus, a German psychologist in 1885, and in turn first introduced into economics by Wright (1936) to describe the effect of learning on production costs in the aircraft industry. 
in order to motivate our approach. Section 3 analyses the relationship between working hours and hourly productivity by employing a variety of empirical methodologies. Finally, Section 4 summarizes with our conclusion and presents some implications.

\section{Working Hours and Productivity: Theoretical Background}

As described above, it has in general been widely accepted that, other things being equal, the response of hourly productivity to a reduction in working hours depends to a large extent upon the initial level of working hours. This may be due to the diverse factors playing roles in affecting a worker's labor efficiency at each level of working hours. The long recognized factor is the "fatigue effect."

Adequate leisure and rest can improve a worker's mental and physical health, so that she will be more relaxed and alert during duty hours, thereby improving her labor productivity. Among others, three mechanisms through which appropriate length of working hours can translate into higher productivity are importantly related to the fatigue effect: physiological effects, motivational effects and improvement of the work organization. The existence of physiological effects means that there is a fundamental nexus between working hours and productivity on the physiological side. For instance, longer working hours are generally perceived to be accommodated for by coordinating the pace or intensity of operation, such as slowing down movements and giving more frequent breaks. Therefore, extending the working hours may not result in as much of an increase in total output as expected, and may rather possibly reduce total output in the long run. On the contrary, a cut in hours can feasibly be in part offset by higher work intensity without bringing about physically detrimental consequences. Secondly, proper working time can have motivational effects by encouraging workers to carry out their duties in more voluntary and efficient ways. Besides this, workers can be given more time to pursue self-development through formal training during their leisure hours. Finally, a reduction in working hours may trigger a series of improvements in work organization, which is conducive to 
productivity gains. For example, while cutting back on regular working hours, the manager and workers may agree on adjusting the organization towards slashing of unnecessary and inefficient wastes of time, thereby enhancing their productivity. This implies that average hourly productivity can decline as the fatigue effect works more strongly with longer hours.

On the other hand, it is likely that a low amount of working hours may be dominated by the influence of the fixed cost channel. That is, a fixed amount of time is required in order for workers to prepare their workplaces or to be given instructions. Therefore, the magnitude of the fixed cost would outweigh that of the fatigue effect within excessively short working hours, such that there might possibly be increasing returns to working time at such interval. This relationship is portrayed as in Figure 2, where the link between working hours and hourly productivity is depicted as hump-shaped. This shows that the economy displays increasing returns to working hours at a short-working-hour range, and that decreasing returns to hours appear at relatively longer hours as the fatigue effect overwhelms the fixed cost effect.

In this paper we posit that there exists an additional channel, a "learning effect" or "skill effect", through which working hours have an impact on hourly productivity. This effect is interpreted as owing to the fact that repetition of the same type of

Figure 2. Relationship between Working Hours and Output

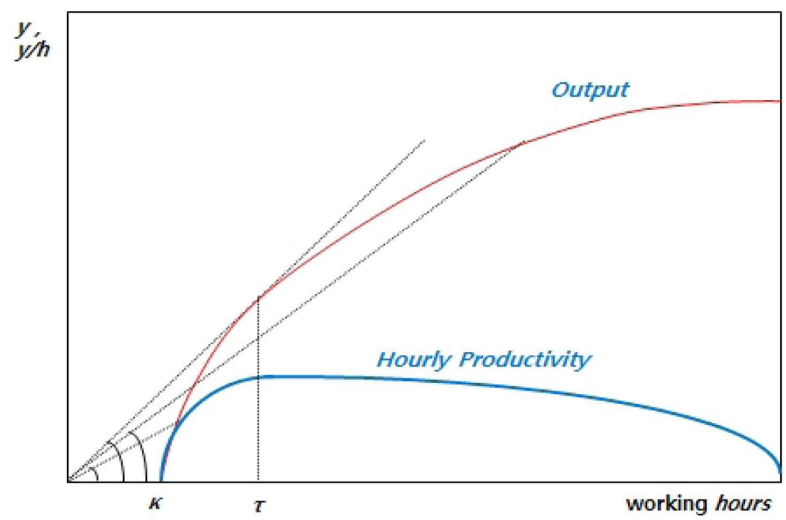

Note : Hourly productivity begins to have positive values at $\kappa$ due to existence of fixed cost and turns to a decreasing trend from $\tau$ which is attributable to the fatigue effect. 
action improves a worker's performance. The manner in which skill acquisition or learning at the workplace works on the worker's productivity can be described in several respects as follows. First, workers become so physically and mentally dextrous by working sufficiently long hours that they can gradually spend less time in preparation, decision-making and the production process, and make much fewer mistakes in operating equipment or machinery. This is true not only of employees but also of managers who are not just those directly involved in production. Next, as managers and laborers become more specialized in their jobs, they can usually find ways of improvement. Finally, full-time activity or specialization enables workers to feel responsible for, and concentrate more on their duties. This relates to classical human capital theory, which predicts that part-time workers should be less productive than full-time workers (Ilmakunnas and Maliranta 2005; Iranzo et al. 2008). And most of the existing literature finds that full-timers are more productive on an hourly basis than part-timers (e.g., Aeronson and French 2004, Baffoe-Bonnie 2004 and Hirsch 2005).

Meanwhile, the classical "learning-by-doing effect" is a concept stating that productivity is acquired through practice, self-perfection, minor innovations etc.. Let us take for example a firm which increases output by learning how to manipulate equipment better without employing additional workers or investing significant amounts of capital.6) In particular, Lucas (1988) employs the learning-by-doing effect to explain increasing returns to embodied human capital. Human capital investment can be divided into two types: formal training and informal learning. Whereas the existing literature has focused largely on formal training, which includes regular schooling, extracurricular courses and job training, increasing attention is now being paid to the role of informal training in worker's productivity. In particular, the informal on-the-job training is divided into two types: learning from one's own experience (self-learning or learning by doing) ${ }^{7)}$ and learning from others (learning by watching) (Barron et al. 1989).

6) The concept of learning-by-doing was first introduced by Arrow in his design of endogenous growth theory to explain effects of innovation and technical change (Arrow 1962).

7) "Self-learning on the job" can be recognized as a process whereby workers improve their productivty through trial and error. 
The accumulation of experience and sufficient learning at the workplace, whether by doing or by watching, enables workers to exercise discretionary behaviour and in turn to attain remarkable performance. That is, at the core of exercising discretionary behaviour is the ability of workers to employ their tacit knowledge of their output process, to identify and generate enhancement in their own and others' performances, and to acquire the skills of problem-solving and decision-making. Most of these skills are presumed to be learned at the workplace (Fuller et al. 2003; Patterson et al. 2003). Borghans et al. (2007) find that the overwhelmingly largest amount of time that is spent on human capital investment is accounted for by informal training. And Weiss (1994) states that the effects of informal training on labor productivity may be substantial. A recent survey conducted in the Netherlands reveals that workers spend approximately $28 \%$ of their working time on informal learning (Nelen and De Grip 2009). Therefore, it seems quite natural to embed the channel of "learning-by-doing" into the nexus between working time and productivity, to the extent that informal learning, which explains the largest fraction of human capital investment, depends positively on the working time and is in turn closely associated with labor productivity.

We now propose a simple theoretical calculation to characterize the way that hourly productivity will respond to working hours. The shape of the learning effect is a graphical representation of the change in productivity (vertical axis) in accordance with the increase in hours (horizontal axis). Although a variety of patterns have been introduced hitherto, what can generally be accepted in an economic sense is $s$-shaped, i.e. beginning slowly at first, then accelerating steeply, and finally slowing down as the practically achievable level of productivity improvement is approached. In this case, productivity begins to improve slowly, then increases rapidly, and finally levels off. This kind of learning model is defined as "learning to learn", since the pace of learning increases with longer working hours as learning builds on what has already been learned. Above a certain point, it becomes ever more difficult to learn and improve things even despite increasing working hours and effort. This shape of learning curves relates to natural limits for technologies (Anzanello and Fogliatto 2011; Sáenz-Royo and 
Salas-Fumás 2013).8) Therefore, a typical learning curve over working time can be expressed as a logistic function:

$$
\frac{y}{h}=\frac{\alpha}{1+\beta e^{-\gamma h}}
$$

where $y$ and $h$ are output and working hours, respectively. $\alpha$ is an upper asymptote at saturation level. $\beta$ is the parameter determining when productivity starts and stops rising. $\gamma$ is the average rate of growth of productivity. The fatigue effect is meanwhile often described by a kind of exponential function such as:

$$
\frac{y}{h}=\frac{\delta\left(1-e^{\eta h}\right)}{h}
$$

where $\delta$ and $\eta$ determine the rate of progress which characterises the speed of decline in hourly productivity. Finally, assuming that without fatigue and learning effects the dependence of output on working hours is linear, the link between productivity and the fixed cost can be expressed as:

$$
\frac{y}{h}=\kappa-\frac{\lambda}{h}
$$

where $\kappa$ denotes constant hourly productivity, controlling for the fatigue effect and the learning effect, $\frac{\lambda}{\kappa}$ stands for the hours spent on preparation for duty without producing at all.

The resulting relationship between a worker's working hours and his/her hourly productivity will depend upon how the three effects described above work together. In other words, while the fixed cost effect and the learning effect should work toward increasing productivity over the working hours, the fatigue effect will work in the opposite direction. Figure 3 displays the several paths of the learning

8) A typical learning model relates to the pace of learning over time and the contribution of learning to productivity. We apply this concept to the linkage between working time, learning and productivity in static terms. 


\section{Figure 3. Scenarios of Learning Effects by the Parameter Values}

A. Parameter $\beta$

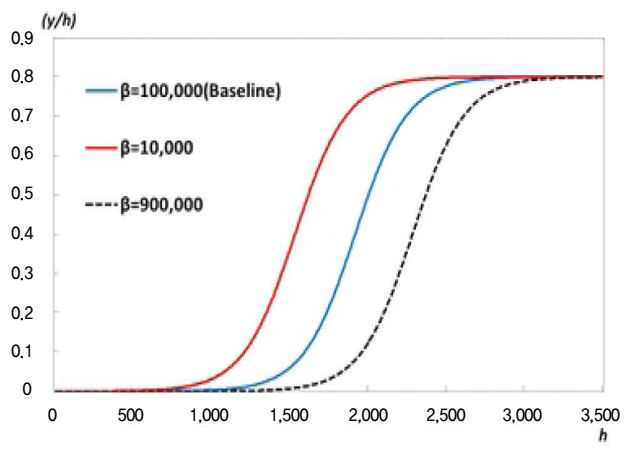

B. Paramete $\gamma$

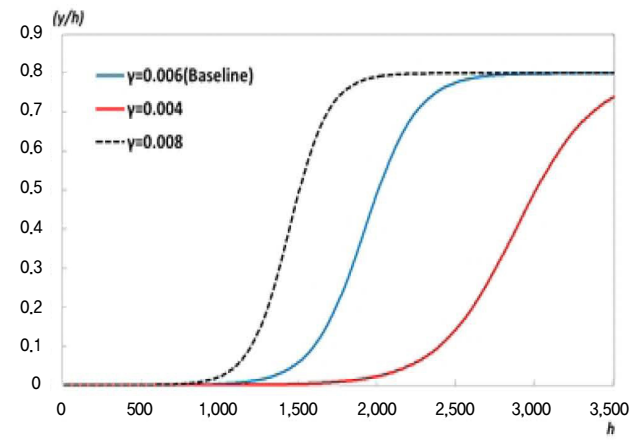

effect, depending upon the parameter values in 1 . The smaller $\beta$ is, the earlier the hourly productivity starts to soar with the working hours. Let us set $\beta=100,000$ as our baseline parameter.9) When $\beta=10,000$; productivity will develop earlier at approximately 1,000 hours per year, that is 19.2 hours in a week, and will reach its maximum level earlier than in the baseline scenario. And the larger $\gamma$ is, the narrower the range at which the learning effect works is. Once we set $\gamma=0.04$, the learning effect should hold even above longer than 3,500 hours in a year.

Meanwhile, Figure 4 depicts the three paths of the fatigue effect. As $\delta$ becomes larger, the productivity diminishes faster. Figure 5 shows that, as $\lambda$ becomes larger, positive effect of workingt hours on productivity via fixed cost channel will last until the hours reach a higher threshold of working hours, since it takes a longer time to prepare for operation without anything being produced.

We combine the three effects and then calculate the dependence of hourly productivity on working hours. We assume that without the three effects an additional one hour's work increases output by 10 dollars. Figure 6 depicts the relationship between working hours and productivity under our baseline scenario (i.e., $\beta=100,000 ; \gamma=0.006 ; \delta=1,000 ; \lambda=1,300$ ). This figure shows clearly that, if there is no learning effect whatever, the relationship between productivity and working hours is characterized by a smooth inverse $u$-shaped functional form.

9) The parameter values of the baseline scenario herein are set to match the shape of fitted elasticities of hourly productivity to average yearly working hours in the next section. 
Figure 4. Scenarios of Fatigue Effects by the Parameter $\delta$

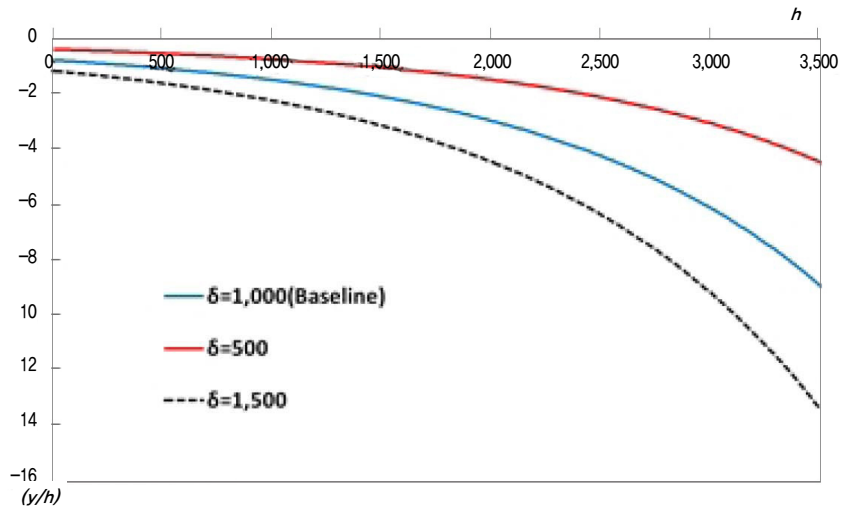

Figure 5. Scenarios of Fixed Cost Effects by the Parameter $\lambda$

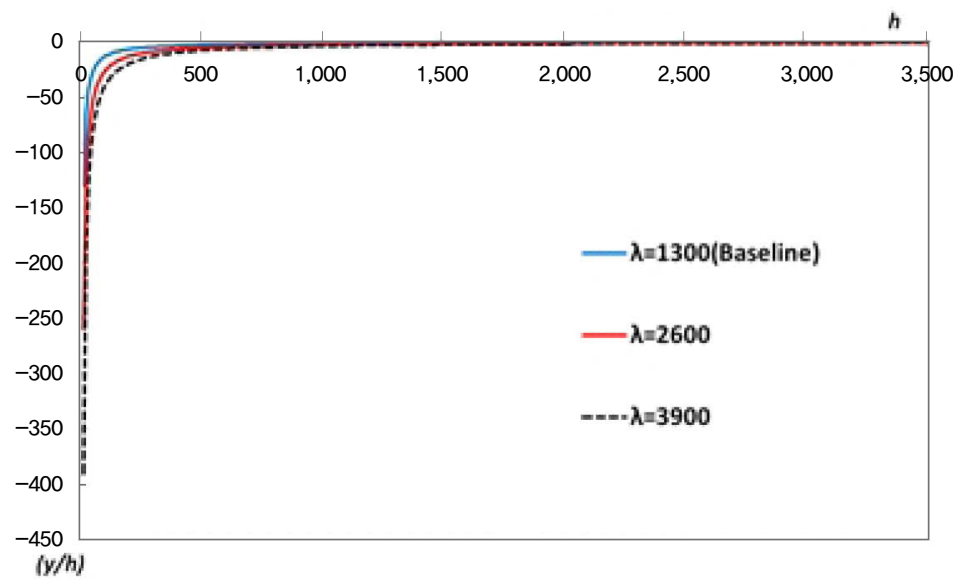

Considering that working 1,000 hours annually means that an employee stays on duty 3.8 hours per day on average, less than 1,000 hours of working time is not accepted as realistic in practice. It is thus observed that without the learning effect the hourly productivity keeps decreasing with higher working hours up to a certain threshold. In contrast, if the learning effect is considered, the shape of the curve turns out to be sinuate. Therefore, to examine whether there exists a learning effect in the nexus between productivity and working hours, it is necessary to test for the nonlinearity in the relationship between the two variables. 


\section{Figure 6. Hourly Productivity Function}

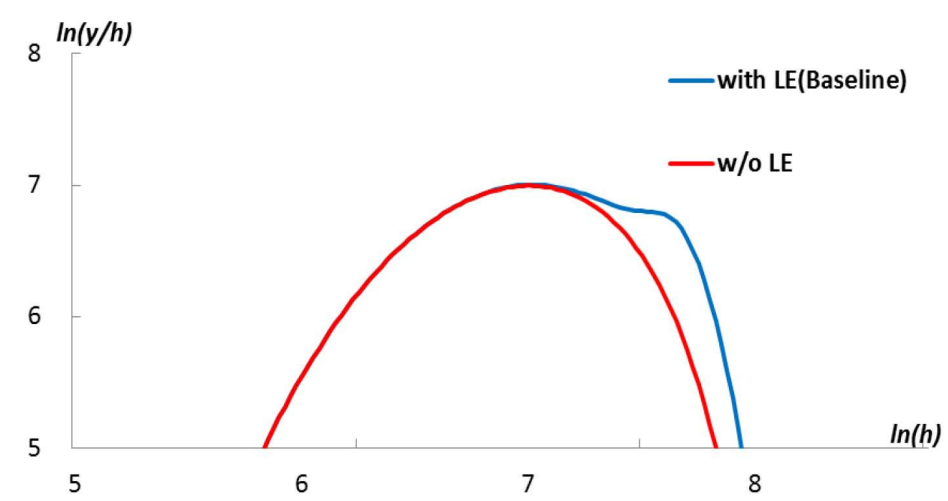

Note : This figure displays the simulation result of the relationship between log-linearized working hours and log-linearized hourly productivity under baseline scenario $(\beta=100,000 ; \gamma=0.006 ; \delta=1,000 ; \lambda=1,300)$ and compares it to that without learning effect.

Meanwhile, the shapes of the curves depend upon the magnitudes and the effective ranges of the effects. As described above, a higher $\beta$ implies that the worker's productivity begins to improve at relatively higher working hours, and a larger $\gamma$ denotes a narrower range of learning effect. Figure 7 reveals that if the learning effect starts to grow steeper at lower working hours than the fatigue effect, i.e. lower $\beta$, the productivity, which would otherwise turn to a decrease at around 1,000 hours due to the dominance of the fatigue effect, continue to rise, since the learning effect dominates, and finally turns to a decrease at around 2,000 hours. In contrast, provided that the learning effect begins to occur at a higher amount of working hours than the fatigue effect, the economy turns to a path of decreasing returns to hours early and then persists on the path afterwards, albeit with some fluctuation driven by the learning effect.

And if the worker's learning takes place over a wide span of time, i.e. lower $\gamma$, the shape of the curve looks analogous to the case with no learning effect, because the learning effect is offset and dominated by the fatigue effect. In contrast, the curve takes on a twisty form in the case where the worker's learning is concentrated in a narrow range.

Figure 8 illustrates that the less intense the fatigue effect is, i.e. lower $\delta$, the later the curve turns to decreasing returns and the twistier it is. And as $\lambda$ becomes 
Figure 7. Sensitivity Analysis of Hourly Productivity: Simulation I

\section{A. Parameter $\beta$}

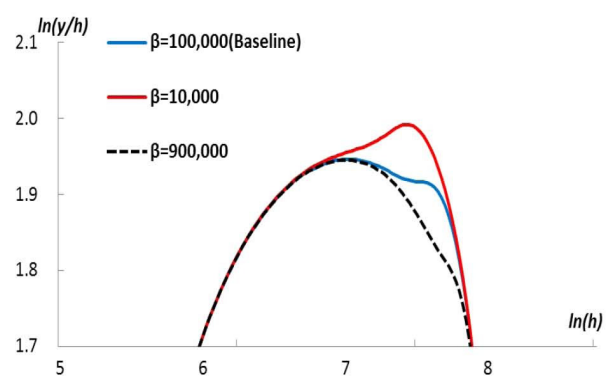

Note : This figure displays the simulation results of relationship between log-linearized working hours and log-linearized hourly productivity, alternating the values of the parameter $\beta$.

\section{B. Parameter $\delta$}

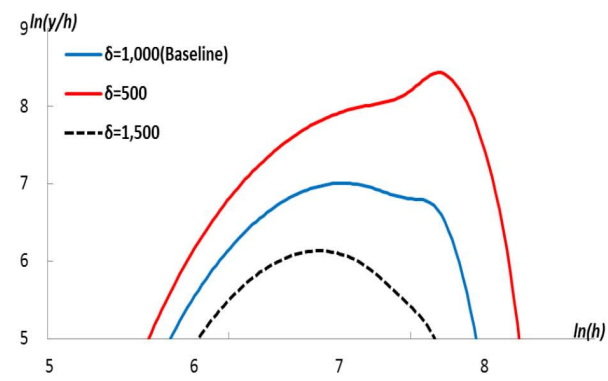

Note : This figure displays the simulation results of relationship between log-linearized working hours and log-linearized hourly productivity, alternating the values of the parameter $\delta$.

larger, i.e. as more time is taken in preparation for operations, the positive effect of the fixed cost on productivity dominates the negative one due to the fatigue effect, so that the economy turns to decreasing returns at relatively higher hours as shown in Figure 9. In effect, a combination of fixed cost and fatigue does not yield a serious nonlinearity in estimation as it is only at very low working hours that the fixed cost affects productivity. But the simulation results consistently reveal that the consideration of the learning effect calls for renewed attention to the need to test for nonlinearity in the relationship between productivity and working hours. What should be borne in mind is that, in any case, the response of productivity to the working hours may well be captured in a nonlinear way rather than by a linear function. It should be particularly the case that more than two effects work together. In the next section we attempt to investigate the presence of the learning effect in the productivity-working time nexus. To this end, we employ a threshold regression methods for our analysis. 
Figure 8. Sensitivity Analysis of Hourly Productivity: Simulation II

Parameter $\delta$

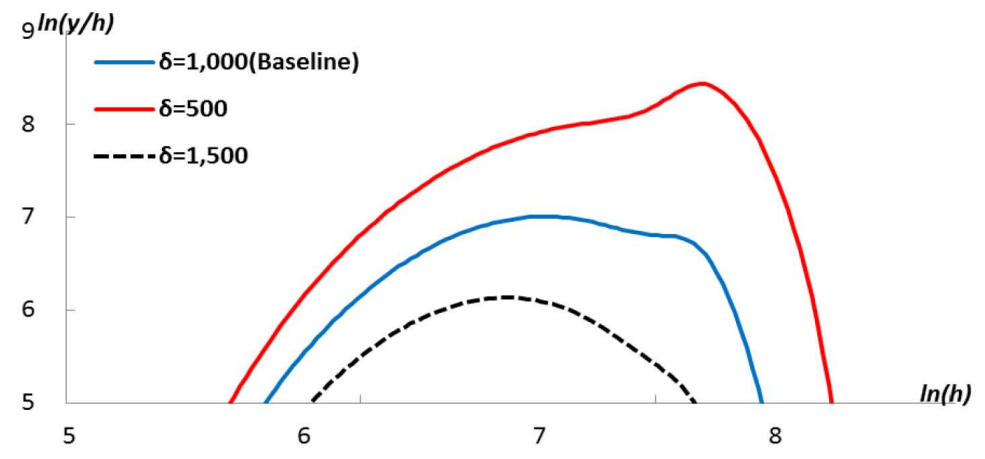

Note : This figure displays the simulation results of relationship between log-linearized working hours and log-linearized hourly productivity, alternating the values of the parameter $\delta$.

Figure 9. Sensitivity Analysis of Hourly Productivity: Simulation III Parameter $\lambda$

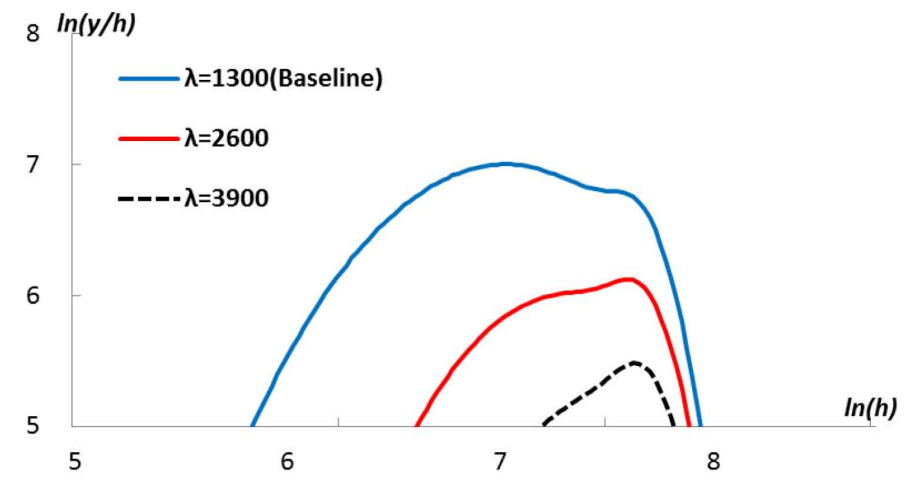

Note : This figure displays the simulation results of relationship between log-linearized working hours and log-linearized hourly productivity, alternating the values of the parameter $\lambda$. 


\section{Working Hours and Productivity: Empirical Analysis}

This section analyses the relationship between working time and hourly productivity by employing a variety of empirical methodologies. We adopt the panel data estimation method considering both industry-specific and time-specific fixed effects, and also attempt to find the thresholds for changes in the relationship using threshold regression methods. Our empirical estimation employs two main approaches: the Cobb-Douglas production function and the translog production function. We will begin by briefly describing the data used for our empirical analysis.

\subsection{Data}

The data used in the empirical analysis come mostly from the EU KLEMS database, which provides industry-level information on value added, labor, capital, and productivity.10) As the original data on values are provided in each country's currency, we convert them to US dollar terms using the PPP (purchasing power parity) exchange rates. ${ }^{11)}$ The detailed definitions of the variables are as follows:

- Value added (or Gross output) ( $Y$ ): Gross value added (Gross output) at current basic prices / Gross value added (Gross output) price indices $(1995=100)$

- Capital stock $(K)$ : Real fixed capital stock at 1995 prices

- Average working hours $(H)$ : Total hours worked by employees $(\widetilde{H})$ / Number of employees $\left.(E)^{12}\right)$

10) This paper uses the EU KLEMS database released in March 2008, as the data for capital stocks are not available in the database more recently released. Refer to Inklaar and Timmer (2008) and O'Mahony and Timmer (2009) for the detailed explanation of this database.

11) The data construction is implemented in two steps: (i) converting the data in local currency for 1997 to those in US dollar terms using the industry-level PPP exchange rates in 1997 from the EU KLEMS database; and (ii) extrapolating them to the other years using the country-level PPP exchange rates in each year from the OECD statistics.

12) We use the data on employees instead of those on all persons engaged, because our attention is paid mainly to the linkage between employees' average working time and productivity. 
- Intermediate inputs $(M)$ : Intermediate inputs at current purchaser's prices / Intermediate input price indices $(1995=100)$

- Total factor productivity $(A)$ : The industry-level total factor productivity (TFP) in 1995 is calculated using the industry-level labor income share $\left(\alpha_{i}\right)$ in 1995 from the EU KLEMS database. ${ }^{13)}$ We then construct the TFPs of the other years through extrapolation methods using the TFP growth rates from the EU KLEMS database.

The estimation is conducted on country-industry panel data for OECD countries. Due to data constraints with capital stocks our sample is limited to 15 countries ${ }^{14}$ ) and 21 industries (13 industries in manufacturing and 8 in services). See the Appendix for the detailed industry classification used in this paper.

\subsection{Cobb-Douglas production function}

We first estimate the Cobb-Douglas production function using an industry-country panel from 1970 to 2005.15) To our knowledge most of the previous literature that examines the relationship between working hours and growth estimates the Cobb-Douglas production function using industry panel data for single countries (e.g., Hart and McGregor 1988; Ilmakunnas 1994; Anxo and Bigsten 1989; Leslie and Wise 1980). Estimation of the production function using country-industry panel data is able to provide more general (not country-specific) results on the relationship between working time and growth. ${ }^{16)}$ The general form of the Cobb-Douglas production function is as follows:

13) Assuming the Cobb-Douglas production function, the TFP of industry $i$ in 1995 can be calculated from the equation $A_{i}=\left(\widetilde{H}_{i}^{\alpha_{i}} K_{i}^{1-\alpha_{i}}\right) / Y_{i}$. The labor income share $\alpha_{i}$ is calculated by $\alpha_{i}=L A B_{i} /\left(L A B_{i}+C A P_{i}\right)$, where $L A B_{i}$ is labor compensation and $C A P_{i}$ is capital compensation from the EU KLEMS database.

14) Australia, Austria, Czech Republic, Denmark, Finland, Germany, Italy, Japan, Korea, Netherlands, Portugal, Slovenia, Sweden, United Kingdom, United States.

15) The panel dataset used in the empirical estimation is unbalanced, since for some countries or industries the data on certain variables are not available.

16) Griffith et al. (2004) also use country-industry panel data to explore the role of R\&D in the growth of productivity in OECD countries. 


$$
Y_{i t}=A_{i t} H_{i t}^{\alpha_{h}} E_{i t}^{\alpha_{e}} K_{i t}^{\alpha_{k}}
$$

where $Y$ is value added, $A$ is TFP, $H$ is the average working hours per employee, $E$ is the number of employees, $K$ is capital stock, and the subscripts $i$ and $t$ denote the industry and the year respectively. Note that, by definition, the product of $H$ and $E$ equals the total hours worked $(\widetilde{H})$. Taking the natural logarithms of the variables and using lower case letters to represent them, we have our CobbDouglas production function as:

$$
y_{i t}=a_{i t}+\alpha_{h} h_{i t}+\alpha_{e} e_{i t}+\alpha_{k} k_{i t}+\mu_{i}+\eta_{t}+\epsilon_{i t}
$$

We control for unobserved heterogeneity correlated with the explanatory variables by allowing the error term to include a country-industry specific fixed effect $\left(\mu_{i}\right)$. There may also be common macroeconomic shocks that affect industry outputs in all countries, and we therefore allow the error term to include a full set of year dummies $\left(\eta_{t}\right)$.

For a robustness check, we consider the intermediate inputs $(M)$ as additional inputs for production. The production function analogous to (5) is then:

$$
y_{i t}=a_{i t}+\alpha_{h} h_{i t}+\alpha_{e} e_{i t}+\alpha_{k} k_{i t}+\alpha_{m} m_{i t}+\mu_{i}+\eta_{t}+\epsilon_{i t}
$$

where $y_{i t}$ stands for the natural log of gross output instead of that of value added. Table 1 presents the coefficients estimated by fixed effects panel regression for two different specifications based on equations (5) and (6). The table also displays the results by industry.17) In our baseline model [1], we estimate equation (5) which includes labor and capital as inputs. The coefficients of all input factors (e.g.,

17) Here the total industry is termed as the sum of the manufacturing and service sectors used in the empirical estimation of this paper (see the Appendix for a detailed industry classification). Therefore the total industry does not cover industries such as agriculture, fishing, mining, electricity, construction and public services. 


\section{Table 1. Estimation of Cobb-Douglas Production Function}

\begin{tabular}{|c|c|c|c|c|c|c|}
\hline \multirow{2}{*}{ Specification } & \multicolumn{2}{|c|}{ Total industry } & \multicolumn{2}{|c|}{ Manufacturing } & \multicolumn{2}{|c|}{ Services } \\
\hline & [1] & [2] & [1] & [2] & [1] & [2] \\
\hline a & $\begin{array}{l}0.950^{* * *} \\
(0.024)\end{array}$ & $\begin{array}{l}0.752^{* * *} \\
(0.071)\end{array}$ & $\begin{array}{l}0.956^{* * *} \\
(0.025)\end{array}$ & $\begin{array}{l}0.822^{* * *} \\
(0.031)\end{array}$ & $\begin{array}{l}0.879^{* * *} \\
(0.073)\end{array}$ & $\begin{array}{l}0.740^{* * *} \\
(0.060)\end{array}$ \\
\hline$h$ & $\begin{array}{l}1.012^{* * *} \\
(0.156)\end{array}$ & $\begin{array}{l}0.179^{* *} \\
(0.083)\end{array}$ & $\begin{array}{l}1.009^{* * *} \\
(0.147)\end{array}$ & $\begin{array}{l}0.178^{* * *} \\
(0.050)\end{array}$ & $\begin{array}{l}1.183^{* * *} \\
(0.321)\end{array}$ & $\begin{array}{l}0.579^{* * *} \\
(0.161)\end{array}$ \\
\hline$e$ & $\begin{array}{l}0.493^{* * *} \\
(0.060)\end{array}$ & $\begin{array}{l}0.130^{* * *} \\
(0.026)\end{array}$ & $\begin{array}{l}0.521^{* * *} \\
(0.035)\end{array}$ & $\begin{array}{l}0.122^{* * * *} \\
(0.012)\end{array}$ & $\begin{array}{l}0.492^{* * *} \\
(0.132)\end{array}$ & $\begin{array}{l}0.234^{* * *} \\
(0.066)\end{array}$ \\
\hline k & $\begin{array}{l}0.656^{* * *} \\
(0.028)\end{array}$ & $\begin{array}{l}0.240^{* * *} \\
(0.032)\end{array}$ & $\begin{array}{l}0.688^{* * *} \\
(0.028)\end{array}$ & $\begin{array}{l}0.137^{* * *} \\
(0.013)\end{array}$ & $\begin{array}{l}0.588^{* * *} \\
(0.058)\end{array}$ & $\begin{array}{l}0.281^{* * *} \\
(0.042)\end{array}$ \\
\hline$m$ & - & $\begin{array}{l}0.649^{* * *} \\
(0.035)\end{array}$ & - & $\begin{array}{l}0.784^{* * * *} \\
(0.012)\end{array}$ & - & $\begin{array}{l}0.501^{* * *} \\
(0.037)\end{array}$ \\
\hline constant & $\begin{array}{l}-7.070^{* * *} \\
(1.235)\end{array}$ & $\begin{array}{l}0.798 \\
(0.630)\end{array}$ & $\begin{array}{l}-7.753^{* * *} \\
(1.222)\end{array}$ & $\begin{array}{l}0.794^{* *} \\
(0.390)\end{array}$ & $\begin{array}{l}-7.496^{* * *} \\
(2.391)\end{array}$ & $\begin{array}{l}-1.602 \\
(1.153)\end{array}$ \\
\hline Observations & 7,613 & 7,623 & 4,709 & 4,719 & 2,904 & 2,904 \\
\hline$R^{2}$ & 0.968 & 0.986 & 0.977 & 0.997 & 0.958 & 0.988 \\
\hline
\end{tabular}

Notes: Dependent variable $(Y)$ is value added in specification [1] and gross output in specification [2]. Numbers in parentheses are robust standard errors. $*, * *$ and $* * *$ indicate coefficient estimates significantly different from zero at the $10 \%, 5 \%$ and $1 \%$ levels respectively. All regressions include full sets of time dummies and full sets of country-industry interactions.

working hours, employment and capital) are significant for all industries. The estimated elasticity of output to working time $\left(\alpha_{h}\right)$ is roughly 1.0 to 1.2 , which is consistent with previous studies. ${ }^{18)}$ Meanwhile, the elasticity of output to employment $\left(\alpha_{e}\right)$ is around 0.5 and that to capital $\left(\alpha_{k}\right)$ roughly 0.6 to 0.7 . It is notable that $\alpha_{k}$ is larger in manufacturing than in services which may be attributable to the fact that industries in manufacturing are generally more capital-intensive.

We also examine the robustness of the results from our baseline model by estimating equation (6) in which intermediate inputs are added as additional

18) In the previous studies there exist large differences in the elasticity of output to working hours. In some studies the estimated elasticity with respect to hours is below one, while it is above one in other studies. In addition, the empirical regularity that the output-hours elasticity is larger than the output-employment elasticity, found in many previous studies due to measurement errors (Estevão 1996), is also found in our estimations. See Table 9 in Ilmakunnas (1994) concerning the elasticity of output to working hours from the previous literature. 
explanatory variables. With intermediate inputs included, gross output instead of value added is used as the dependent variable $(Y)$. In our auxiliary model [2], we find that the elasticity of output to intermediate inputs $\left(\alpha_{m}\right)$ is estimated at around $0.5 \sim 0.8$ and is significant at $1 \%$ in all industries. The significances of the coefficients are maintained in all industry classifications and the explanatory power $\left(R^{2}\right)$ of estimation is increased with the addition of intermediate inputs, while the levels of the coefficients for the other inputs decline to large extents.

Up until now, we have implicitly assumed a uniform and linear relationship between working hours and productivity. As explained in the previous section, however, the relative importances of the "fatigue effect" and the "learning effect" depending upon the initial level of working hours may produce a nonlinear relationship between working hours and productivity. We therefore attempt here to find thresholds for the link between working time and productivity.

We follow the method proposed by Hansen (1999) and adopted in Cecchetti et al. (2011) examining the threshold for the effect of debt on economic growth.19) As seen in Figure 6, there may exist multiple thresholds depending upon the relative importances of the "fatigue effect" and the "learning effect" from the extension of working hours. We also find that there exist at least one and at most four significant changes in the relationship between working hours and productivity, in accordance with the model specifications and by industry. Our model is therefore set up to have multiple (at most four) thresholds:

$$
\begin{aligned}
y_{i t}= & a_{i t}+\alpha_{h 0} h_{i t}+\alpha_{h 1} h_{i t} \cdot I\left(h_{i t} \geq \tau_{1}\right)+\alpha_{h 2} h_{i t} \cdot I\left(h_{i t} \geq \tau_{2}\right)+\alpha_{h 3} h_{i t} \cdot I\left(h_{i t} \geq \tau_{3}\right) \\
& +\alpha_{h 4} h_{i t} \cdot I\left(h_{i t} \geq \tau_{4}\right)+\alpha_{e} e_{i t}+\alpha_{k} k_{i t}+\mu_{i}+\eta_{t}+\epsilon_{i t}
\end{aligned}
$$

where the thresholds are ordered as $\tau_{1}<\tau_{2}<\tau_{3}<\tau_{4}$, and $\mathrm{I}(\cdot)$ is an indicator variable that takes the value of 1 if the working time is above or equal to a

19) Hansen (1999) has developed threshold regression methods for non-dynamic panel data models, which have been used in many applications. 
threshold and zero otherwise.20) Each indicator variable has the effect of splitting the working time variable into two, allowing its impact on productivity to differ above and below the threshold. Note that equations (7) and (8) are identical to equations (5) and (6) except for the threshold effects.

We estimate equation (7) and (8) for a series of working hours with a 10-hour grid, and then select the one that minimizes the sum of the squared errors. Following Hansen (1999) we look for the thresholds in a sequential way, by estimating equation (7) and (8) by alternating the thresholds from the lowest to the highest.21) We test whether the addition of each threshold is significant or not using a standard Wald test. It is notable that, similar to our models, Cette et al. (2011) hypothesize that the presence of the fatigue effect should cause the returns of working hours to decrease at a greater rate above certain thresholds. However, they introduce three thresholds alternately, not all at once, to find the existence of the fatigue effect without considering the learning effect. Moreover, the threshold levels considered in their estimations are arbitrarily chosen.

Table 2 presents the coefficients and the threshold levels estimated using equations (7) and (8). For simplicity of discussion, we focus on the coefficients of the variables related to working hours. In both [1] and [2] for total industry, we can identify three or four significant thresholds: (i) at 1,670 1,710 hours per year (32 33 hours per week); (ii) 2,030 2,080 hours (39 40 hours); (iii) 2,710 hours (52 hours); and (iv) 3,070 3,100 hours (59 60 hours). The elasticity of output to working time $\left(\alpha_{h}\right)$ declines significantly after the working time reaches the first threshold $\left(\tau_{1}\right)$, rises from the second threshold $\left(\tau_{2}\right)$, then declines again from the third threshold $\left(\tau_{3}\right)$ and finally declines further from the fourth threshold $\left(\tau_{4}\right)$.

20) Specifying the indicator variable as in (7) is identical to setting the model up as:

$$
\begin{aligned}
y_{i t}=a_{i t}+\beta_{h 0} h_{i t} \cdot I\left(h_{i t}<\tau_{1}\right) & +\beta_{h 1} h_{i t} \cdot I\left(\tau_{1} \leq h_{i t}<\tau_{2}\right)+\beta_{h 2} h_{i t} \cdot I\left(\tau_{2} \leq h_{i t}<\tau_{3}\right)+\beta_{h 3} h_{i t} \cdot I\left(\tau_{3} \leq h_{i t}<\tau_{4}\right) \\
& +\beta_{h 4} h_{i t} \cdot I\left(h_{i t} \geq \tau_{4}\right)+\beta_{e} e_{i t}+\beta_{k} k_{i t}+\mu_{i}+\eta_{t}+\epsilon_{i t}
\end{aligned}
$$

The coefficients of the two equations have the relationship of $\alpha_{h 0}=\beta_{h 0} ; \alpha_{h 1}=\beta_{h 1}-\beta_{h 0} ; \alpha_{h 2}=\beta_{h 2}-\beta_{h 1}$; $\alpha_{h 3}=\beta_{h 3}-\beta_{h 2} ; \alpha_{h 4}=\beta_{h 4}-\beta_{h 3}$ This relationship can be easily induced by using the following identity:

$$
I\left(h_{i t}<\tau_{1}\right)+I\left(\tau_{1} \leq h_{i t}<\tau_{2}\right)+I\left(\tau_{2} \leq h_{i t}<\tau_{3}\right)+I\left(\tau_{3} \leq h_{i t}<\tau_{4}\right)+I\left(h_{i t} \geq \tau_{4}\right)=1 \text { for all } i .
$$

Equation (8) can be explained in a similar way.

21) Hansen (1999) shows that sequential estimation is consistent and asymptotically efficient in the multiple threshold model. The insight and logic is similar to those for the multiple change point model (Bai 1997; Bai and Perron 1998). 


\section{Table 2. Threshold Estimation of Cobb-Douglas Production Function}

\begin{tabular}{|c|c|c|c|c|c|c|}
\hline \multirow{2}{*}{ Specification } & \multicolumn{2}{|c|}{ Total industry } & \multicolumn{2}{|c|}{ Manufacturing } & \multicolumn{2}{|c|}{ Services } \\
\hline & [1] & [2] & [1] & [2] & [1] & [2] \\
\hline$a$ & $\begin{array}{l}0.945^{* * *} \\
(0.023)\end{array}$ & $\begin{array}{l}0.759^{* * *} \\
(0.065)\end{array}$ & $\begin{array}{l}0.949^{* * *} \\
(0.023)\end{array}$ & $\begin{array}{l}0.824^{* * *} \\
(0.030)\end{array}$ & $\begin{array}{l}0.901^{* * *} \\
(0.065)\end{array}$ & $\begin{array}{l}0.762^{* * *} \\
(0.049)\end{array}$ \\
\hline$h$ & $\begin{array}{l}1.030^{* * *} \\
(0.151)\end{array}$ & $\begin{array}{l}0.302^{* * *} \\
(0.099)\end{array}$ & $\begin{array}{l}0.970^{* * *} \\
(0.139)\end{array}$ & $\begin{array}{l}0.166^{* * *} \\
(0.050)\end{array}$ & $\begin{array}{l}1.272^{* * *} \\
(0.263)\end{array}$ & $\begin{array}{l}0.668^{* * *} \\
(0.126)\end{array}$ \\
\hline$h \cdot I\left(h \geq \tau_{1}\right)$ & $\begin{array}{l}-0.0056^{* * *} \\
(0.0018)\end{array}$ & $\begin{array}{l}-0.0033^{* * *} \\
(0.0014)\end{array}$ & $\begin{array}{l}-0.0071^{* * *} \\
(0.0022)\end{array}$ & - & - & - \\
\hline$h \cdot I\left(h \geq \tau_{2}\right)$ & $\begin{array}{l}0.0149^{* * *} \\
(0.0030)\end{array}$ & $\begin{array}{l}0.0046^{* * *} \\
(0.0012)\end{array}$ & $\begin{array}{l}0.0159^{* * *} \\
(0.0035)\end{array}$ & $\begin{array}{l}0.0025^{* *} \\
(0.0010)\end{array}$ & $\begin{array}{l}0.0146^{* *} \\
(0.0063)\end{array}$ & $\begin{array}{l}0.0052^{* *} \\
(0.0022)\end{array}$ \\
\hline$h \cdot I\left(h \geq \tau_{3}\right)$ & - & $\begin{array}{l}-0.0132^{* * *} \\
(0.0029)\end{array}$ & $\begin{array}{l}-0.0252^{* * *} \\
(0.0073)\end{array}$ & $\begin{array}{l}-0.0103^{* * *} \\
(0.0031)\end{array}$ & - & $\begin{array}{l}-0.0144^{*} \\
(0.0083)\end{array}$ \\
\hline$h \cdot I\left(h \geq \tau_{4}\right)$ & $\begin{array}{l}-0.0323^{* *} \\
(0.0154)\end{array}$ & $\begin{array}{l}-0.0144^{* * *} \\
(0.0036)\end{array}$ & - & $\begin{array}{l}-0.0039^{* *} \\
(0.0018)\end{array}$ & $\begin{array}{l}-0.0785^{* * *} \\
(0.0257)\end{array}$ & $\begin{array}{l}-0.0330^{* * *} \\
(0.0126)\end{array}$ \\
\hline$e$ & $\begin{array}{l}0.509^{* * *} \\
(0.055)\end{array}$ & $\begin{array}{l}0.150^{* * *} \\
(0.025)\end{array}$ & $\begin{array}{l}0.528^{* * *} \\
(0.033)\end{array}$ & $\begin{array}{l}0.125^{* * *} \\
(0.012)\end{array}$ & $\begin{array}{l}0.556^{* * *} \\
(0.121)\end{array}$ & $\begin{array}{l}0.276^{* * *} \\
(0.061)\end{array}$ \\
\hline$k$ & $\begin{array}{l}0.643^{* * *} \\
(0.026)\end{array}$ & $\begin{array}{l}0.226 * * * \\
(0.030)\end{array}$ & $\begin{array}{l}0.677^{* * *} \\
(0.026)\end{array}$ & $\begin{array}{l}0.137^{* * *} \\
(0.013)\end{array}$ & $\begin{array}{l}0.553^{* * *} \\
(0.054)\end{array}$ & $\begin{array}{l}0.266^{* * *} \\
(0.041)\end{array}$ \\
\hline$m$ & - & $\begin{array}{l}0.636 * * * \\
(0.034)\end{array}$ & - & $\begin{array}{l}0.779^{* * *} \\
(0.012)\end{array}$ & - & $\begin{array}{l}0.492^{* * *} \\
(0.033)\end{array}$ \\
\hline constant & $\begin{array}{l}-7.144^{* * *} \\
(1.176)\end{array}$ & $\begin{array}{l}0.026 \\
(0.717)\end{array}$ & $\begin{array}{l}-7.360^{* * *} \\
(1.121)\end{array}$ & $\begin{array}{l}0.900^{* * *} \\
(0.396)\end{array}$ & $\begin{array}{l}-8.006^{* * *} \\
(1.976)\end{array}$ & $\begin{array}{l}-2.168^{* *} \\
(0.936)\end{array}$ \\
\hline Observations & 7,613 & 7,623 & 4,709 & 4,719 & 2,904 & 2,904 \\
\hline$R^{2}$ & 0.970 & 0.987 & 0.979 & 0.997 & 0.962 & 0.989 \\
\hline$\tau_{1}$ & 1,670 & 1,710 & 1,670 & - & - & - \\
\hline$\tau_{2}$ & 2,080 & 2,030 & 2,090 & 2,080 & 2,070 & 2,030 \\
\hline$\tau_{3}$ & - & 2,710 & 2,390 & 2,390 & - & 2,820 \\
\hline$\tau_{4}$ & 3,100 & 3,070 & - & 3,100 & 3,060 & 3,100 \\
\hline \multicolumn{7}{|c|}{ Wald test for significance of thresholds: } \\
\hline F-statistic & 12.96 & 12.22 & 15.36 & 7.83 & 6.82 & 4.88 \\
\hline$p$-value & 0.000 & 0.000 & 0.000 & 0.000 & 0.002 & 0.003 \\
\hline
\end{tabular}

Notes: Dependent variable $(Y)$ is value added in specification [1] and gross output in specification [2]. Numbers in parentheses are robust standard errors. *, ** and *** indicate coefficient estimates significantly different from zero at the $10 \%, 5 \%$ and $1 \%$ levels respectively. All regressions include full sets of time dummies and full sets of country-industry interactions.

These results imply that: (i) the prominence of the fatigue effect at very short working hours causes the elasticity to decline; (ii) the influence of the learning effect at around 40 hours per week leads the elasticity to begin to surge; (iii) the weakening of the learning effect at considerably long working hours causes the elasticity to drop; and finally (iv) the strengthening of the fatigue effect at very long working hours leads the elasticity to drop further. This empirical finding is 
consistent with our theoretical conjecture on the relationship between working hours and productivity in Section 2, more specifically in Figure 6.

The relationship between working hours and productivity, which is determined mainly by the fatigue effect and the learning effect, may differ between manufacturing and services since the input elasticities and the roles of skills vary across industries. In our estimation results, the numbers and the levels of thresholds vary extensively across industries. First of all, in specification [1] only the second threshold $\left(\tau_{2}\right)$ is identified in services, while three thresholds $\left(\tau_{1}, \tau_{2}\right.$ and $\left.\tau_{3}\right)$ are identified in manufacturing. The insignificance of $\tau_{3}$ in services, which is considered as a threshold related to the inflection point of the learning effect, may imply that the learning effect is relatively not so substantial in services. In specification [2] three thresholds $\left(\tau_{2}, \tau_{3}\right.$ and $\left.\tau_{4}\right)$ are significant in both manufacturing and services. Secondly, the third threshold $\left(\tau_{3}\right)$ is found at around 46 hours of work per week in manufacturing, while it is identified at around 55 hours in services in specification [2] where $\tau_{3}$ is significant. This difference may result from the fact that the weakening of the learning effect begins to arise at a lower level of working hours in manufacturing than in services.

In addition, we test the significance of the included thresholds using a standard Wald test. As seen in the bottom rows of Table 2, the included thresholds are significant at the $1 \%$ level for both model specifications and all industries.

By rearranging equations (5) and (6) and using $\tilde{h}_{i t}=\ln \left(H_{i t} \cdot E_{i t}\right)$, the elasticity of hourly productivity to working time $\left(\epsilon_{h}\right)$ is given by:

$$
\epsilon_{i t}^{h} \equiv \frac{d\left(y_{i t}-\tilde{h}_{i t}\right)}{d h_{i t}}=\alpha_{h}-1
$$

The elasticities of productivity to working time $\left(\epsilon_{h}\right)$ for each working time interval, which are determined by the thresholds identified in Table 2 can be calculated using (9) and the estimated parameters. Table 3 shows the results. It is noticeable that the elasticity of hourly productivity to working time increases in regression [1] on total industry and services. The positive elasticity (i.e., $\epsilon_{h}>0$ ) in services may be attributable to the fact that the fatigue effect is relatively less 
Table 3. Elasticity of Productivity to Working Time: Cobb-Douglas Function

\begin{tabular}{|c|c|c|c|c|c|c|}
\hline \multirow{2}{*}{ Elasticity } & \multicolumn{2}{|c|}{ Total industry } & \multicolumn{2}{|c|}{ Manufacturing } & \multicolumn{2}{|c|}{ Services } \\
\hline & [1] & [2] & [1] & [2] & [1] & [2] \\
\hline$h<\tau_{1}$ & 0.030 & -0.698 & -0.030 & \multirow{2}{*}{-0.834} & \multirow{2}{*}{0.272} & \multirow{2}{*}{-0.332} \\
\hline$\tau_{1} \leq h<\tau_{2}$ & 0.024 & -0.701 & -0.037 & & & \\
\hline$\tau_{2} \leq h<\tau_{3}$ & \multirow{2}{*}{0.039} & -0.697 & -0.021 & -0.831 & \multirow{2}{*}{0.287} & -0.327 \\
\hline$\tau_{3} \leq h<\tau_{4}$ & & -0.710 & \multirow{2}{*}{-0.046} & -0.842 & & -0.341 \\
\hline$h \geq \tau_{4}$ & 0.007 & -0.724 & & -0.846 & 0.208 & -0.374 \\
\hline
\end{tabular}

Note: If the coefficients of the interaction terms of working time and the threshold dummies are not significant at the $10 \%$ level, they are considered as being the same as those at the lower working time intervals.

substantial in services than in manufacturing. However, note that in regression [2] controlling for intermediate inputs as explanatory variables, hourly productivity decreases with longer working hours in both manufacturing and services. The important finding is that in any model specification and industry scope, there exists a range of workng hours in which the elasticities of productivity to working time rise siginificantly owing to the learning effect.

\subsection{Translog production function}

In this subsection we estimate the translog production function which is obtained by a second-order approximation using Taylor series (Christensen et al. 1973). The translog production function is more flexible and more general than the Cobb-Douglas production function, since it allows interaction among the input factors (Østbye 2010). Anxo and Bigsten (1989) estimate both the Cobb-Douglas and the translog production functions, and find that the elasticities of output to working hours may differ significantly depending upon the functional forms used in the estimation.22) The translog production functions analogous to (5) and (6) are:

22) Pablo-Romero and Góez-Calero (2013) also estimate a translog production function, to examine the impacts of physical and human capital on economic growth considering the interactions among the input factors. 


$$
\begin{aligned}
y_{i}= & a_{i t}+\alpha_{h} h_{i t}+\alpha_{e} e_{i t}+\alpha_{k} k_{i t}+\alpha_{h h} h_{i t}^{2}+\alpha_{e e} e_{i t}^{2}+\alpha_{k k} k_{i t}^{2} \\
& +a_{h e} h_{i t} \cdot e_{i t}+\alpha_{h k} h_{i t} \cdot k_{i t}+\alpha_{e k} e_{i t} \cdot k_{i t}+\mu_{i}+\eta_{t}+\epsilon_{i t} ; \\
y_{i t}= & a_{i t}+\alpha_{h} h_{i t}+\alpha_{e} e_{i t}+\alpha_{k} k_{i t}+\alpha_{m} m_{i t}+\alpha_{h h} h_{i t}^{2}+\alpha_{e e} e_{i t}^{2}+\alpha_{k k} k_{i t}^{2} \\
& +\alpha_{m m} m_{i t}^{2}+\alpha_{h e} h_{i t} \cdot e_{i t}+\alpha_{h k} h_{i t} \cdot k_{i t}+\alpha_{h m} h_{i t} \cdot m_{i t}+\alpha_{e k} e_{i t} \cdot k_{i t} \\
& +\alpha_{e m} e_{i t} \cdot m_{i t}+\alpha_{k m} k_{i t} \cdot m_{i t}+\mu_{i}+\eta_{t}+\epsilon_{i t} .
\end{aligned}
$$

Regarding the functional forms of production, we test the significance of the inclusion of additional variables (i.e., interaction terms and square terms of inputs) from the Cobb-Douglas production function using a standard Wald test. In all model specifications and industry coverage the test results reveal the inclusion of supplementary variables to be significant at the $1 \%$ level. These results imply that the translog production function may have some advantages over the Cobb-Douglas production function in characterising the production technology of the industry panel data used in our empirical analysis.

Table 4 reports the coefficients estimated by fixed effects panel regression for two different specifications based on (10) and (11) and by industry. As the translog production function allows interaction among the inputs and a nonlinear relationship between inputs and outputs, the estimates differ extensively in magnitude and significance from those for the Cobb-Douglas production function reported in Table 1.

For simplicity of discussion, we focus on the coefficients of variables related to working time. Among the estimates, only the coefficient estimates for the interaction term between working hours and employment $(h \cdot e)$ are consistently significant. This result may be attributable to the fact that working hours may affect total output mainly through the effects on human resources rather than through capital stock or intermediate inputs. The positive coefficient on the interaction term implies that with other things being equal, an increase in working hours leads to an increase in margianl productivity of employment which may reflect the existence of learning effect.23) Meanwhile, the coefficients on both the level of working hours

23) From (10) and (11), the coefficient of the interaction of working time and employment is calculated as $\alpha_{h e}=\frac{\partial}{\partial h}\left(\frac{\partial y}{\partial e}\right)=\frac{\partial}{\partial e}\left(\frac{\partial y}{\partial h}\right)$ 
$(h)$ and the square of working hours $\left(h_{2}\right)$ are insignificant in most model specifications and for different industry scopes. These results imply that changes in working time may affect outputs and thereby productivity mainly through the impact on employment, and that the effects also vary depending upon the initial level of employment. Therefore the link between working hours and employment is a decisive factor determining the relationship between working time and hourly productivity.

As seen from Table 4, under the translog technology the important channel through which working hours affect productivity (or output) is their impact on employment. We therefore employ four thresholds for the interaction term of working hours and employment. ${ }^{24)}$ Similar to the estimation of the Cobb-Douglas production function, we estimate equations (12) and (13) by alternating the thresholds in terms of working hours with a 10-hour grid and then select the hours that minimizes the sum of the squared errors. Notice that equations (12) and (13) are identical to equations (10) and (11) except for the threshold effects:

$$
\begin{aligned}
y_{i t}= & a_{i t}+\alpha_{h} h_{i t}+\alpha_{e} e_{i t}+\alpha_{k} k_{i t}+\alpha_{h h} h_{i t}^{2}+\alpha_{e e} e_{i t}^{2}+\alpha_{k k} k_{i t}^{2}+\alpha_{h e 0} h_{i t} \cdot e_{i t} \\
& +a_{h e 1} h_{i t} \cdot e_{i t} \cdot I\left(h_{i t} \geq \tau_{1}\right)+\alpha_{h e 2} h_{i t} \cdot e_{i t} \cdot I\left(h_{i t} \geq \tau_{2}\right) \\
& +a_{h e 3} h_{i t} \cdot e_{i t} \cdot I\left(h_{i t} \geq \tau_{3}\right)+\alpha_{h e 4} h_{i t} \cdot e_{i t} \cdot I\left(h_{i t} \geq \tau_{4}\right) \\
& +\alpha_{h k} h_{i t} \cdot k_{i t}+\alpha_{e k} e_{i t} \cdot k_{i t}+\mu_{i}+\eta_{t}+\epsilon_{i t} \\
y_{i t}= & a_{i t}+\alpha_{h} h_{i t}+\alpha_{e} e_{i t}+\alpha_{k} k_{i t}+\alpha_{m} m_{i t}+\alpha_{h h} h_{i t}^{2}+\alpha_{e e} e_{i t}^{2}+\alpha_{k k} k_{i t}^{2}+\alpha_{m m} m_{i t}^{2} \\
& +\alpha_{h e 0} h_{i t} \cdot e_{i t}+\alpha_{h e 1} h_{i t} \cdot e \cdot I\left(h_{i t} \geq \tau_{1}\right)+\alpha_{h e 2} h_{i t} \cdot e_{i t} \cdot I\left(h_{i t} \geq \tau_{2}\right) \\
& +\alpha_{h e 3} h_{i t} \cdot e_{i t} \cdot I\left(h_{i t} \geq \tau_{3}\right)+\alpha_{h e 4} h_{i t} \cdot e_{i t} \cdot I\left(h_{i t} \geq \tau_{4}\right)+\alpha_{h k} h_{i t} \cdot k_{i t} \\
& +\alpha_{h m} h_{i t} \cdot m_{i t}+\alpha_{e k} e_{i t} \cdot k_{i t}+\alpha_{e m} e_{i t} \cdot m_{i t}+\mu_{i}+\eta_{t}+\epsilon_{i t} .
\end{aligned}
$$

Table 5 reports the coefficients and the threshold levels estimated using equations (12) and (13). In specifications [1] and [2] on total industry, we can identify four significant thresholds: (i) 1,660 1,710 hours per year (32 33 hours per week); (ii) 2,030 2,080 hours (39 40 hours); (iii) 2,710 2,850 hours (52 55

24) The numbers and levels of thresholds are not significantly affected by employing thresholds on either $h$ or $h \cdot e$. We therefore report the estimation results in the case of employing thresholds on $h \cdot e$. The results of employing thresholds on $h$ can be provided upon request. 


\section{Table 4. Estimation of Translog Production Function}

\begin{tabular}{|c|c|c|c|c|c|c|}
\hline \multirow{2}{*}{ Specification } & \multicolumn{2}{|c|}{ Total industry } & \multicolumn{2}{|c|}{ Manufacturing } & \multicolumn{2}{|c|}{ Services } \\
\hline & {$[1]$} & {$[2]$} & {$[1]$} & [2] & {$[1]$} & [2] \\
\hline a & $\begin{array}{l}0.956^{* * *} \\
(0.024)\end{array}$ & $\begin{array}{l}0.692^{* * *} \\
(0.052)\end{array}$ & $\begin{array}{l}0.952^{* * * *} \\
(0.022)\end{array}$ & $\begin{array}{l}0.826^{* * *} \\
(0.031)\end{array}$ & $\begin{array}{l}0.899^{* * *} \\
(0.065)\end{array}$ & $\begin{array}{l}0.711^{* * *} \\
(0.066)\end{array}$ \\
\hline$h$ & $\begin{array}{l}5.771 \\
(7.680)\end{array}$ & $\begin{array}{l}8.491^{* *} \\
(3.572)\end{array}$ & $\begin{array}{l}3.824 \\
(5.797)\end{array}$ & $\begin{array}{r}-0.394 \\
(1.970)\end{array}$ & $\begin{array}{l}1.676 \\
(9.808)\end{array}$ & $\begin{array}{l}6.694 \\
(5.282)\end{array}$ \\
\hline$e$ & $\begin{array}{l}-1.742^{* * *} \\
(0.528)\end{array}$ & $\begin{array}{l}-0.684^{* * *} \\
(0.246)\end{array}$ & $\begin{array}{l}-1.939^{* * *} \\
(0.644)\end{array}$ & $\begin{array}{l}-0.699^{* * *} \\
(0.213)\end{array}$ & $\begin{array}{l}-3.628^{* * *} \\
(0.908)\end{array}$ & $\begin{array}{l}-1.228^{* * *} \\
(0.522)\end{array}$ \\
\hline$k$ & $\begin{array}{l}0.741^{* * *} \\
(0.202)\end{array}$ & $\begin{array}{r}-0.506 \\
(0.576)\end{array}$ & $\begin{array}{l}0.375 \\
(0.279)\end{array}$ & $\begin{array}{l}-0.197 \\
(0.441)\end{array}$ & $\begin{array}{l}1.145^{* * *} \\
(0.237)\end{array}$ & $\begin{array}{l}0.664 \\
(0.719)\end{array}$ \\
\hline$m$ & - & $\begin{array}{l}1.463^{* * *} \\
(0.573)\end{array}$ & - & $\begin{array}{l}1.185^{* * *} \\
(0.439)\end{array}$ & - & $\begin{array}{l}0.338 \\
(0.782)\end{array}$ \\
\hline$h^{2}$ & $\begin{array}{l}-0.431 \\
(0.510)\end{array}$ & $\begin{array}{l}-0.592^{* *} \\
(0.237)\end{array}$ & $\begin{array}{r}-0.332 \\
(0.395)\end{array}$ & $\begin{array}{l}0.0143 \\
(0.133)\end{array}$ & $\begin{array}{c}-0.191 \\
(0.666)\end{array}$ & $\begin{array}{r}-0.443 \\
(0.348)\end{array}$ \\
\hline$e^{2}$ & $\begin{array}{l}0.003 \\
(0.011)\end{array}$ & $\begin{array}{l}0.005 \\
(0.006)\end{array}$ & $\begin{array}{l}-0.007 \\
(0.007)\end{array}$ & $\begin{array}{l}0.014 \\
(0.003)\end{array}$ & $\begin{array}{l}0.023 \\
(0.021)\end{array}$ & $\begin{array}{l}0.014 \\
(0.012)\end{array}$ \\
\hline$k^{2}$ & $\begin{array}{l}-0.003^{*} \\
(0.002)\end{array}$ & $\begin{array}{l}0.040^{* * *} \\
(0.010)\end{array}$ & $\begin{array}{l}-0.003^{* *} \\
(0.001)\end{array}$ & $\begin{array}{l}0.018^{* * * *} \\
(0.007)\end{array}$ & $\begin{array}{l}-0.001 \\
(0.004)\end{array}$ & $\begin{array}{l}0.012 \\
(0.014)\end{array}$ \\
\hline$m^{2}$ & - & $\begin{array}{l}0.058^{* * *} \\
(0.008)\end{array}$ & - & $\begin{array}{l}0.024^{* * *} \\
(0.007)\end{array}$ & - & $\begin{array}{l}0.024^{*} \\
(0.014)\end{array}$ \\
\hline$h \cdot e$ & $\begin{array}{l}0.303^{* * *} \\
(0.072)\end{array}$ & $\begin{array}{l}0.080^{* *} \\
(0.032)\end{array}$ & $\begin{array}{l}0.328^{* * *} \\
(0.090)\end{array}$ & $\begin{array}{l}0.091^{* * *} \\
(0.029)\end{array}$ & $\begin{array}{l}0.549^{* * *} \\
(0.117)\end{array}$ & $\begin{array}{l}0.169^{* * *} \\
(0.064)\end{array}$ \\
\hline$h \cdot k$ & $\begin{array}{l}0.001 \\
(0.025)\end{array}$ & $\begin{array}{l}0.033 \\
(0.072)\end{array}$ & $\begin{array}{l}0.049 \\
(0.036)\end{array}$ & $\begin{array}{l}0.015 \\
(0.056)\end{array}$ & $\begin{array}{l}-0.063^{* *} \\
(0.030)\end{array}$ & $\begin{array}{l}-0.072 \\
(0.086)\end{array}$ \\
\hline$h \cdot m$ & - & $\begin{array}{l}-0.027 \\
(0.072)\end{array}$ & - & $\begin{array}{l}0.022 \\
(0.054)\end{array}$ & - & $\begin{array}{l}0.058 \\
(0.093)\end{array}$ \\
\hline$e \cdot k$ & $\begin{array}{l}-0.003 \\
(0.010)\end{array}$ & $\begin{array}{l}0.041^{* * *} \\
(0.008)\end{array}$ & $\begin{array}{l}0.005 \\
(0.005)\end{array}$ & $\begin{array}{l}0.025^{* * *} \\
(0.005)\end{array}$ & $\begin{array}{r}-0.014 \\
(0.015)\end{array}$ & $\begin{array}{l}0.017 \\
(0.013)\end{array}$ \\
\hline$e \cdot m$ & - & $\begin{array}{l}-0.047^{* * *} \\
(0.007)\end{array}$ & - & $\begin{array}{l}-0.026^{* * *} \\
(0.005)\end{array}$ & - & $\begin{array}{l}-0.024^{* *} \\
(0.012)\end{array}$ \\
\hline$k \cdot m$ & - & $\begin{array}{l}-0.098^{* * *} \\
(0.018)\end{array}$ & - & $\begin{array}{l}-0.042^{* * *} \\
(0.014)\end{array}$ & - & $\begin{array}{c}-0.037 \\
(0.028)\end{array}$ \\
\hline Constant & $\begin{array}{l}-19.10 \\
(28.82)\end{array}$ & $\begin{array}{l}-26.99^{* *} \\
(13.65)\end{array}$ & $\begin{array}{l}-10.50 \\
(21.23)\end{array}$ & $\begin{array}{l}4.69 \\
(7.44)\end{array}$ & $\begin{array}{l}-0.78 \\
(35.95)\end{array}$ & $\begin{array}{l}-22.04 \\
(20.35)\end{array}$ \\
\hline Observations & 7,613 & 7,623 & 4,709 & 4,719 & 2,904 & 2,904 \\
\hline$R^{2}$ & 0.971 & 0.992 & 0.981 & 0.997 & 0.962 & 0.990 \\
\hline
\end{tabular}

Notes: Dependent variable $(Y)$ is value added in specification [1] and gross output in specification [2]. Numbers in parentheses are robust standard errors. *, ** and $* * *$ indicate coefficient estimates significantly different from zero at the $10 \%, 5 \%$ and $1 \%$ levels respectively. All regressions include full sets of time dummies and full sets of country-industry interactions. 
Table 5. Threshold Estimation of Translog Production Function

\begin{tabular}{|c|c|c|c|c|c|c|}
\hline \multirow{2}{*}{ Specification } & \multicolumn{2}{|c|}{ Total industry } & \multicolumn{2}{|c|}{ Manufacturing } & \multicolumn{2}{|c|}{ Services } \\
\hline & {$[1]$} & [2] & {$[1]$} & [2] & [1] & [2] \\
\hline$a$ & $\begin{array}{l}0.951^{* * *} \\
(0.023)\end{array}$ & $\begin{array}{l}0.701^{* * *} \\
(0.047)\end{array}$ & $\begin{array}{l}0.949 * * * \\
(0.022)\end{array}$ & $\begin{array}{l}0.827^{* * *} \\
(0.030)\end{array}$ & $\begin{array}{l}0.900^{* * *} \\
(0.064)\end{array}$ & $\begin{array}{l}0.718^{* * *} \\
(0.061)\end{array}$ \\
\hline$h$ & $\begin{array}{l}-0.289 \\
(6.076)\end{array}$ & $\begin{array}{l}4.700^{*} \\
(2.684)\end{array}$ & $\begin{array}{l}0.924 \\
(5.868)\end{array}$ & $\begin{array}{l}-1.209 \\
(1.962)\end{array}$ & $\begin{array}{l}7.288 \\
(10.920)\end{array}$ & $\begin{array}{l}5.216 \\
(4.259)\end{array}$ \\
\hline$e$ & $\begin{array}{l}-1.678^{* * *} \\
(0.555)\end{array}$ & $\begin{array}{l}-0.762^{* * *} \\
(0.252)\end{array}$ & $\begin{array}{l}-1.702^{* * *} \\
(0.593)\end{array}$ & $\begin{array}{l}-0.675^{* * *} \\
(0.207)\end{array}$ & $\begin{array}{l}-3.059^{* * *} \\
(0.799)\end{array}$ & $\begin{array}{l}-0.853 \\
(0.550)\end{array}$ \\
\hline$k$ & $\begin{array}{l}0.821^{* * *} \\
(0.195)\end{array}$ & $\begin{array}{l}-0.473 \\
(0.528)\end{array}$ & $\begin{array}{l}0.468^{*} \\
(0.273)\end{array}$ & $\begin{array}{l}-0.050 \\
(0.442)\end{array}$ & $\begin{array}{l}1.078^{* * *} \\
(0.247)\end{array}$ & $\begin{array}{l}0.554 \\
(0.695)\end{array}$ \\
\hline$m$ & - & $\begin{array}{l}1.460^{* * *} \\
(0.532)\end{array}$ & - & $\begin{array}{l}1.078^{* *} \\
(0.434)\end{array}$ & - & $\begin{array}{l}0.368 \\
(0.768)\end{array}$ \\
\hline$h^{2}$ & $\begin{array}{l}-0.007 \\
(0.407)\end{array}$ & $\begin{array}{l}-0.334^{*} \\
(0.181)\end{array}$ & $\begin{array}{l}-0.122 \\
(0.402)\end{array}$ & $\begin{array}{l}0.080 \\
(0.134)\end{array}$ & $\begin{array}{l}-0.553 \\
(0.741)\end{array}$ & $\begin{array}{l}-0.333 \\
(0.286)\end{array}$ \\
\hline$e^{2}$ & $\begin{array}{l}-0.001 \\
(0.010)\end{array}$ & $\begin{array}{l}0.004 \\
(0.006)\end{array}$ & $\begin{array}{l}-0.007 \\
(0.006)\end{array}$ & $\begin{array}{l}0.004 \\
(0.003)\end{array}$ & $\begin{array}{l}0.020 \\
(0.021)\end{array}$ & $\begin{array}{l}0.010 \\
(0.012)\end{array}$ \\
\hline$k^{2}$ & $\begin{array}{l}-0.003^{*} \\
(0.002)\end{array}$ & $\begin{array}{l}0.039 * * * \\
(0.010)\end{array}$ & $\begin{array}{l}-0.003^{* *} \\
(0.001)\end{array}$ & $\begin{array}{l}0.018^{* * *} \\
(0.006)\end{array}$ & $\begin{array}{l}-0.002 \\
(0.004)\end{array}$ & $\begin{array}{l}0.013 \\
(0.013)\end{array}$ \\
\hline$m^{2}$ & - & $\begin{array}{l}0.057^{* * *} \\
(0.008)\end{array}$ & - & $\begin{array}{l}0.024^{* * *} \\
(0.007)\end{array}$ & - & $\begin{array}{l}0.026^{*} \\
(0.013)\end{array}$ \\
\hline$h \cdot e$ & $\begin{array}{l}0.296 * * * \\
(0.076)\end{array}$ & $\begin{array}{l}0.090 * * * \\
(0.032)\end{array}$ & $\begin{array}{l}0.294^{* * *} \\
(0.083)\end{array}$ & $\begin{array}{l}0.087^{* * * *} \\
(0.028)\end{array}$ & $\begin{array}{l}0.474^{* * *} \\
(0.106)\end{array}$ & $\begin{array}{l}0.121^{*} \\
(0.068)\end{array}$ \\
\hline$h \cdot e \cdot I\left(h \geq \tau_{1}\right)$ & $\begin{array}{l}-0.0008^{* *} \\
(0.0004)\end{array}$ & $\begin{array}{l}-0.0004^{*} \\
(0.0002)\end{array}$ & - & $\begin{array}{l}-0.0003^{*} \\
(0.0002)\end{array}$ & - & - \\
\hline$h \cdot e \cdot I\left(h \geq \tau_{2}\right)$ & $\begin{array}{l}0.0017^{* * *} \\
(0.0004)\end{array}$ & $\begin{array}{l}0.0004^{* *} \\
(0.0002)\end{array}$ & $\begin{array}{l}0.0011^{* *} \\
(0.0005)\end{array}$ & $\begin{array}{l}0.0003^{*} \\
(0.0002)\end{array}$ & $\begin{array}{l}0.0027^{* *} \\
(0.0012)\end{array}$ & $\begin{array}{l}0.0011^{*} \\
(0.0007)\end{array}$ \\
\hline$h \cdot e \cdot I\left(h \geq \tau_{3}\right)$ & $\begin{array}{l}-0.0023^{*} \\
(0.0013)\end{array}$ & $\begin{array}{l}-0.0017^{* * *} \\
(0.0006)\end{array}$ & $\begin{array}{l}-0.0046^{* * *} \\
(0.0016)\end{array}$ & $\begin{array}{l}-0.0009^{*} \\
(0.0005)\end{array}$ & - & $\begin{array}{l}-0.0044^{*} \\
(0.0024)\end{array}$ \\
\hline$h \cdot e \cdot I\left(h \geq \tau_{4}\right)$ & $\begin{array}{l}-0.0069^{* *} \\
(0.0027)\end{array}$ & $\begin{array}{l}-0.0027^{* *} \\
(0.0012)\end{array}$ & $\begin{array}{l}-0.0021^{* *} \\
(0.0010)\end{array}$ & $\begin{array}{l}-0.0009^{* * *} \\
(0.0003)\end{array}$ & - & - \\
\hline$h \cdot k$ & $\begin{array}{l}-0.013 \\
(0.025)\end{array}$ & $\begin{array}{l}0.027 \\
(0.067)\end{array}$ & $\begin{array}{l}0.035 \\
(0.035)\end{array}$ & $\begin{array}{l}-0.005 \\
(0.056)\end{array}$ & $\begin{array}{l}-0.057^{*} \\
(0.032)\end{array}$ & $\begin{array}{l}-0.062 \\
(0.085)\end{array}$ \\
\hline$h \cdot m$ & - & $\begin{array}{l}-0.027 \\
(0.068)\end{array}$ & - & $\begin{array}{l}-0.008 \\
(0.054)\end{array}$ & - & $\begin{array}{l}0.057 \\
(0.093)\end{array}$ \\
\hline$e \cdot k$ & $\begin{array}{l}-0.000 \\
(0.009)\end{array}$ & $\begin{array}{l}0.044^{* * *} \\
(0.008)\end{array}$ & $\begin{array}{l}0.007 \\
(0.005)\end{array}$ & $\begin{array}{l}0.026^{* * *} \\
(0.005)\end{array}$ & $\begin{array}{l}-0.012 \\
(0.015)\end{array}$ & $\begin{array}{l}0.021^{*} \\
(0.012)\end{array}$ \\
\hline$e \cdot m$ & - & $\begin{array}{l}-0.048^{* * *} \\
(0.007)\end{array}$ & - & $\begin{array}{l}-0.027^{* * *} \\
(0.005)\end{array}$ & - & $\begin{array}{l}-0.026^{* *} \\
(0.012)\end{array}$ \\
\hline$k \cdot m$ & - & $\begin{array}{l}-0.097^{* * *} \\
(0.017)\end{array}$ & - & $\begin{array}{l}-0.041^{* * *} \\
(0.014)\end{array}$ & - & $\begin{array}{l}-0.040 \\
(0.026)\end{array}$ \\
\hline Constant & $\begin{array}{l}2.68 \\
(22.64)\end{array}$ & $\begin{array}{l}-12.96 \\
(10.06)\end{array}$ & $\begin{array}{l}-0.46 \\
(21.39)\end{array}$ & $\begin{array}{l}7.44 \\
(7.34)\end{array}$ & $\begin{array}{l}-22.34 \\
(40.01)\end{array}$ & $\begin{array}{l}-16.97 \\
(16.23)\end{array}$ \\
\hline Observations & 7,613 & 7,623 & 4,709 & 4,719 & 2,904 & 2,904 \\
\hline$R^{2}$ & 0.973 & 0.992 & 0.981 & 0.997 & 0.963 & 0.990 \\
\hline$\tau_{1}$ & 1,660 & 1,710 & - & 1,710 & - & - \\
\hline$\tau_{2}$ & 2,080 & 2,030 & 2,080 & 2,080 & 2,070 & 2,100 \\
\hline$\tau_{3}$ & 2,850 & 2,710 & 2,390 & 2,390 & - & 2,840 \\
\hline$\tau_{4}$ & 3,100 & 3,100 & 3,100 & 3,100 & - & - \\
\hline \multicolumn{7}{|c|}{ Wald test for signficance of thresholds: } \\
\hline F-statistic & 6.03 & 4.07 & 6.23 & 3.93 & 5.04 & 3.04 \\
\hline$P$-value & 0.000 & 0.003 & 0.001 & 0.004 & 0.027 & 0.052 \\
\hline
\end{tabular}

Notes: Dependent variable $(Y)$ is value added in specification [1] and gross output in specification [2]. Numbers in parentheses are robust standard errors. $*, * *$ and $* * *$ indicate coefficient estimates significantly different from zero at the $10 \%, 5 \%$ and $1 \%$ levels respectively. All regressions include full sets of time dummies and full sets of country-industry interactions. 
hours); and (iv) 3,100 hours (60 hours). Note that the identified threshold levels are very similar to those in the threshold estimation with the Cobb-Douglas production function, and the results can thus be interpreted in a similar way. That is, the elasticity of output to working time declines at 32 33 hours per week; rises at 39 40 hours; declines again at 52 55 hours and finally declines further at 60 hours. Notice that the estimation results differ with regard to the numbers of significant thresholds between the manufacturing and service sectors. In specification [1], there are four thresholds identified in manufacturing while only one significant threshold $\left(\tau_{2}\right)$ is identified in services. This fact implies that the weakening of the learning effect is less pronounced and the fatigue effect not so substantial in services. In the specification [2] where intermediate inputs are added to the explanatory variables, three thresholds $\left(\tau_{2}, \tau_{3}\right.$ and $\left.\tau_{4}\right)$ are significant in manufacturing but only two $\left(\tau_{2}\right.$ and $\left.\tau_{3}\right)$ in services.

We also test the significances of the thresholds using a standard Wald test. As seen in the bottom rows of Table 5 , the thresholds are significant at the $1 \%$ level in total industry and the manufacturing sector, and at the $5 \%$ and $10 \%$ levels in the service sector.

By rearranging equations (10) and (11) and using $\tilde{h}_{i t} \equiv \ln \left(H_{i t} \cdot E_{i t}\right)$, the elasticities of hourly productivity to working time are given by:

$$
\begin{gathered}
\epsilon_{i t}^{h} \equiv \frac{d\left(y_{i t}-\tilde{h}_{i t}\right)}{d h_{i t}}=\alpha_{h}-1+2 \alpha_{h h} h_{i t}+\alpha_{h e} e_{i t}+\alpha_{h k} k_{i t} \\
\epsilon_{i t}^{h} \equiv \frac{d\left(y_{i t}-\tilde{h}_{i t}\right)}{d h_{i t}}=\alpha_{h}-1+2 \alpha_{h h} h_{i t}+\alpha_{h e} e_{i t}+\alpha_{h k} k_{i t}+\alpha_{h m} m_{i t}
\end{gathered}
$$

The elasticities of productivity to working time $\left(\epsilon_{h}\right)$ for each working time interval, calculated using (14) and (15), and the estimated parameters, are presented in Table 6 . The elasticities are evaluated at the median values of the input factors. Notice that under the translog technology the elasticity of hourly productivity to working time is decreasing in all model specifications and industries. This result is different from the case with Cobb-Douglas production where there exist some specifications that have increasing elasticities. For total 


\section{Table 6. Elasticity of Productivity to Working Time: Translog Function}

\begin{tabular}{|c|c|c|c|c|c|c|}
\hline \multirow{2}{*}{ Elasticity } & \multicolumn{2}{|c|}{ Total industry } & \multicolumn{2}{|c|}{ Manufacturing } & \multicolumn{2}{|c|}{ Services } \\
\hline & [1] & [2] & [1] & [2] & [1] & [2] \\
\hline$h<\tau_{1}$ & -0.230 & -0.773 & \multirow{2}{*}{-0.241} & -0.721 & \multirow{2}{*}{-0.532} & \multirow{2}{*}{-0.605} \\
\hline$\tau_{1} \leq h<\tau_{2}$ & -0.233 & -0.775 & & -0.723 & & \\
\hline$\tau_{2} \leq h<\tau_{3}$ & -0.226 & -0.773 & -0.236 & -0.721 & \multirow{3}{*}{-0.520} & -0.600 \\
\hline$\tau_{3} \leq h<\tau_{4}$ & -0.236 & -0.781 & -0.256 & -0.725 & & \multirow{2}{*}{-0.619} \\
\hline$h \geq \tau_{4}$ & -0.266 & -0.793 & -0.265 & -0.729 & & \\
\hline
\end{tabular}

Notes: If the coefficients of the interaction terms of working time and the threshold dummies are not significant at the $10 \%$ level, they are considered as being the same as those at the lower working time intervals. Elasticities are evaluated at the median values of the input factors.

industry, the level of elasticity ranges from -0.27 to -0.23 depending upon the level of working hours in specification [1], and from -0.79 to -0.77 in specification [2].25) It is also obvious that the estimates of elasticity vary across the industry coverages and model specifications. Even so, it is notable that there exists a range of workng hours such that elasticities of productivity to working time rise siginificantly owing to the learning effect.

\section{Concluding Remarks}

Recent data have shown that the striking decreases in working hours per capita seen in most countries since the 1970s, which have been sustained over a considerable period, are coupled with productivity improvement. The influence of shorter working hours on workers' labor productivity has thus been a hotly debated issue. As a result, it has been well established that a reduction in working hours leads to productivity gains. However, much still remains to be resolved

25) The levels of elasticity of output to working hours are lower than those in the earlier studies using translog production functions. For instance, in Anxo and Bigsten (1989) the elasticity of output to working hours is estimated at 0.82 0.92 depending upon the model specifications, while our estimates for total industry amount to $0.73 \sim 0.77$ in specification [1] and $0.21 \sim 0.23$ in specification [2]. 
concerning how the changes in working hours influence productivity. This paper focuses attention on a new channel, the learning effect, which has not been highlighted hitherto with regard to this problem but has been recognized as important in human capital, corporate strategy, etc., and attempts to test for nonlinearity in the relationship between the two variables. Our empirical analysis leads to the following main findings. First, we find the presence of two to four thresholds in most specifications, which is strongly supportive of our hypothesis that nonlinearity in the relationship is present. Moreover, in all specifications and functional forms, there exist ranges of working time in which the tendency of productivity declines with the extension of working hours is weakened. This implies the existence of important factors other than the fatigue effect in the productivity-working hours nexus, which we assume in this paper to be the learning effect. To be specific, in an estimation on the total economy, four thresholds are identified: i.e., at approximately 32 hours $\left(\tau_{1}\right), 40$ hours $\left(\tau_{2}\right), 52$ hours $\left(\tau_{3}\right)$ and 60 hours $\left(\tau_{4}\right)$ per week. The elasticity of productivity to working time declines more steeply from $\tau_{1}$, more gently from $\tau_{2}$, more sharply again from $\tau_{3}$ and finally even more sharply from $\tau_{4}$. That is, the worker begins to feel fatigued and increasingly more so from when she works at around 32 hours/week, gains skills and experience on duty between 40 and 60 hours per week, and finally feels only extremely exhausted after more than 60 hours per week.

Second, the shapes of the productivity-hours curves vary across industries. The estimation results show that there are three to four thresholds in manufacturing and one to three thresholds in services. Therefore, we can conclude that the impact of declines in working hours on productivity depends crucially upon the current working hours and the properties of the industry concerned.

Lastly, we do not obtain any result displaying a statistically significant positive elasticity of hourly productivity to working hours even at the lowest working hours, other than in the regressions on total industry and services employing the Cobb-Douglas production function. This result is attributable primarily to the property of the data used in our analyses whereby there are very few observations at extremely low working hours since we employ industry level data, and not individual firm data. It is presumably also in part because the fatigue effect is not 
so relatively substantial in the service sector, and because of the omitted variable problem whereby without the inclusion of intermediate inputs the elasticities are estimated to be increasing, especially in the service sector.

Recently, not a few governments have dictated that firms cut their working hours across the board. However, the results of our study provide policymakers with some implications that it may well not turn out very successful to mandate a uniform cut in working hours, but rather hamper workers' opportunities to accumulate skills or proficiency in their jobs. Therefore, in policymaking related to the reform of regular working time systems, it is imperative to approach this problem with a consideration of a variety of factors, such as current levels of working hours, the features of each industry, the sizes of the firms, etc.

Future research should be extended to that employing the individual- or firm-level data in that the effect of the change in working hours on the hourly productivity is closely associated with individual's preferences for leisure and investment in human capital. 


\section{Appendix: Industry Classification}

For our estimation, we employ the EU KLEMS database which comprise the industry-level information of value added, labor, capital and productivity in OECD member countries. Because of deficiency of the data on capital stocks, we limit the data set to 15 countries and 21 industries. Industry code and classification used in this paper are as follows.

\section{Industry Code and Classification}

\begin{tabular}{|c|c|}
\hline Industry code & Industry Classification \\
\hline \multicolumn{2}{|l|}{$\langle$ Manufacturing $\rangle$} \\
\hline $15-16$ & Food products, beverages and tobacco \\
\hline $17-19$ & Textiles, textile products, leather and footwear \\
\hline 20 & Wood and products of wood and cork \\
\hline $21-22$ & Pulp, paper, paper products, printing and publishing \\
\hline 23 & Coke, refined petroleum products and nuclear fuel \\
\hline 24 & Chemicals and chemical products \\
\hline 25 & Rubber and plastics products \\
\hline 26 & Other non-metallic mineral products \\
\hline $27-28$ & Basic metals and fabricated metal products \\
\hline 29 & Machinery nec \\
\hline 30-33 & Electrical and optical equipment \\
\hline $34-35$ & Transport equipment \\
\hline $36-37$ & Manufacturing nec; recycling \\
\hline \multicolumn{2}{|l|}{ 〈Services〉 } \\
\hline 50 & Sale, maintenance and repair of motor vehicles and motorcycles; retail sale of fuel \\
\hline 51 & Wholesale trade and commission trade, except of motor vehicles and motorcycles \\
\hline 52 & Retail trade, except of motor vehicles and motorcycles; repair of household goods \\
\hline $60-63$ & Transport and storage \\
\hline 64 & Post and telecommunications \\
\hline J & Financial intermediation \\
\hline 70 & Real estate activities \\
\hline $71-74$ & Renting of machinery \& equipment and other business activities \\
\hline
\end{tabular}

Note: Industry codes are consistent with NACE industry classifications. 


\section{References}

Aeronson, D. and E. French (2004), "The Effect of Part-Time Work on Wages: Evidence from the Social Security Rules," Journal of Labor Economics, Vol. 22 No. 2, pp. 329-352.

Andersen, T. M. (1987), "Short- and Long-Run Consequences of Shorter Working Hours," in R. Lund and P. J. Pedersen (eds.), Unemployment Theory, Policy and Structure, Amsterdam: De Gruyte, pp. 147-165.

Anxo, D. (1998), "Working Time: Research and Development," A Review of Literature (1995 97) commissioned by the European Commission and the European Foundation for the Improvement of Living and Working Conditions, Centre for European Labor Market Studies.

Anxo, D. and A. Bigsten (1989), "Working Hours and Productivity in Swedish Manufacturing," The Scandinavian Journal of Economics, 91(3), pp. 613-619.

Anzanello, M. J. and F. S. Fogliatto (2011), "Learning Curve Models and Applications: Literature Review and Research Directions," International Journal of Industrial Ergonomics, Vol. 41, No. 5, pp. 573-583.

Arrow, K. (1962), "The Economic Implications of Learning by Doing," Review of Economic Studies, Vol. 29, No. 3, pp. 155-173.

Bai, J. (1997), "Estimating Multiple Breaks One at a Time," Econometric Theory, Vol. 13, No. 3, pp. 315-352.

Bai, J. and P. Perron (1998), "Estimating and Testing Linear Models with Multiple Structural Changes,” Econometrica, Vol. 66, No. 1, pp. 47-78.

Baffoe-Bonnie, J. (2004), "Interindustry Part-time and Full-time Wage Differentials: Regional and National Analysis," Applied Economics, Vol. 36, No. 2, pp. 107-118.

Barron, J. M., D. A. Black and M. A. Loewenstein (1989), "Job Matching and On-the-job Training," Journal of Labor Economics, Vol. 7, No. 1, pp. 1-19.

Borghans, L., B. Golsteyn and A. De Grip (2007), "Werkend Leren," Economisch Statistische Berichten, Vol. 4, pp. 260-263.

Bourlès, R. and G. Cette (2005), "A Comparison of Structural Productivity Levels in the Major Industrialised Countries," OECD Economic Studies, No. 41, pp. 96-138. 
Bourlès, R. and G. Cette (2007), "Trends in Structural Productivity Levels in the Major Industrialized Countries," Economics Letters, Vol. 95, No. 1, pp. 151-156. Cecchetti, S. G., M. S. Mohanty and F. Zampolli (2011), "The Real Effects of Debt," Bank for International Settlements, Monetary and Economic Department.

Cette, G., S. Chang and M. Konte (2011), "The Decreasing Returns on Working Time: An Empirical Analysis on Panel Country Data," Applied Economics Letters, Vol. 18, No. 17, pp. 1677-1682.

Christensen, L. R., D. W. Jorgenson and L. J. Lau (1973), "Transcendental Logarithmic Production Frontiers," The Review of Economics and Statistics, Vol. 55, No. 1, pp. 28-45.

Craine, R. (1973), "On the Service Flow from Labour," The Review of Economic Studies, Vol. 40, No. 1, pp. 39-46.

Cueva S. and E. Heyer (1998), "Fonction De Production et Degrés D’utilisation du Capital et du Travail: Une Analyse Éonométrique," (Production Function and Degrees of Use of Capital and Labour: An Econometric Analysis), Economie et prévision, No. 131.

Dew-Becker, I. and R. J. Gordon (2008), “The Role of Labour Market Changes in the Slowdown of European Productivity Growth," Discussion Paper Series, CEPR, No. 6722, February.

Estevão, Marcello (1996), "Measurement Error and Time Aggregation: A Closer Look at Estimates of Output-Labor Elasticities," Federal Reserve Board, Finance and Economics Discussion Series, No. 96-2.

Evans, Dwyfor A., C. J. Green and V. Murinde (2002), "Human Capital and Financial Development in Economic Growth: New Evidence Using the Translog Production Function," International Journal of Finance \& Economics, Vol. 7, No. 2, pp. 123-140.

Feldstein, M. S. (1967), "Specification of the Labour Input in the Aggregate Production Function," Review of Economic Studies, 34, pp. 375-86.

Fuller, A., D. Ashton, A. Felstead, L. Unwin, S. Walters and M. Quinn (2003), The Impact of Informal Learning at Work on Business Productivity, DTI Skills Research Programme, London: Department for Trade and Industry.

Griffith, R., S. Redding and J. Van Reenen (2004), "Mapping the Two Faces of 
R\&D: Productivity Growth in a Panel of OECD Industries," The Review of Economics and Statistics, Vol. 86, No. 4, pp. 883-895.

Gust, C. and J. Marquez (2000), "Productivity Developments Abroad," Federal Reserve Bulletin, October.

Gust, C. and J. Marquez (2004), "International Comparisons of Productivity Growth: The Role of Information Technology and Regulatory Practices," Labour Economics, Vol. 11, No. 1, pp. 33-58.

Hansen, B. E. (1999), “Threshold Effects in Non-Dynamic Panels: Estimation, Testing, and Inference,” Journal of Econometrics, Vol. 93, No. 2, pp. 345-368.

Hart, R. A. (1984), "Worksharing and Factor Prices," European Economic Review, Vol. 24, No. 2, pp. 165-188.

Hart, R. and P. McGregor (1988), "The Return to Labour Service in West German Manufacturing Industry," European Economic Review, Vol. 32, No. 4, pp. 947-963.

Hirsch, B. T. (2005), "Why Do Part-time Workers Earn Less? The Role of Worker and Job Skills," Industrial and Labor Relations Review, Vol. 58, No. 4, pp. 525-551.

Hoel, M. (1987), “Can Shorter Working Time Reduce Unemployment?” in C.-H. Siven (ed), Unemployment in Europe, Timbro, Stockholm.

Huang, C. C., J. J. Chang, C. C. Lai and C. C. Lin (2002), "Worker Productivity, Working Time Reduction, And The Short-Run And Long-Run Employment Effects," Scottish Journal of Political Economy, Vol. 49, No. 4, pp. 357-368.

Ilmakunnas, P. (1994), "Returns to Workers and Hours in Finnish Manufacturing," Empirical Economics, Vol. 19, No. 4, pp. 533-553.

Ilmakunnas, P. and M. Maliranta (2005), “Technology, Labour Characteristics and Wage-Productivity Gaps," Oxford Bulletin of Economics and Statistics, Vol. 67, No. 5, pp. 623-645.

Inklaar, R. and M. Timmer (2008), "GGDC Productivity Level Database: International Comparisons of Output, Inputs and Productivity at the Industry Level," Groningen Growth and Development Centre Research Memorandum GD-104, Groningen: University of Groningen.

Iranzo, S., F. Schivardi and E. Tosetti (2008), "Skill Dispersion and Firm Productivity: 
An Analysis with Employer-Employee Matched Data," Journal of Labor Economics, Vol. 26, No. 2, pp. 247-285.

Leslie, D. (1984), "The Productivity of Hours in US Manufacturing Industries," The Review of Economics and Statistics, Vol. 66, No. 3, pp. 486-490.

Leslie, D. and J. White (1980), "The Productivity of Hours in UK Manufacturing and Production Industries," The Economic Journal, Vol. 90, No. 357, pp. 74-84.

Lucas, Robert (1988), "On the Mechanics of Economic Development," Journal of Monetary Economics, Vol. 22, No. 1, pp. 3-42.

Malinvaud, E. (1973), "Une Explication de la Productivite Horaire du Travail," Eonomie et Statistique, Vol. 48.

McGuckin, R. and B. Van Ark (2005), "Productivity and Participation: An International Comparison," Research Memorandum, University of Groningen, Groningen Growth and Development Centre, August.

Nelen, A. and A. De Grip (2009), "Why Do Part-Time Workers Invest Less in Human Capital than Full-Timers?," Labour, Vol. 23, No. s1, pp. 61-83.

O'Mahony, M. and M. P. Timmer (2009), "Output, Input and Productivity Measures at the Industry Level: The EU KLEMS Database," The Economic Journal, Vol. 119, No. 538, F374-F403.

Østbye, S. (2010), “The Translog Growth Model," Journal of Macroeconomics, Vol. 32, No. 2, pp. 635-640.

Pablo-Romero, M. D. P. and M. Góez-Calero (2013), "A Translog Production Function for the Spanish Provinces: Impact of the Human and Physical Capital in Economic Growth," Economic Modelling, Vol. 32, pp. 77-87.

Patterson, M. G., M. A. West and T. D. Wall (2003), "Integrated Manufacturing, Empowerment and Company Performance," Journal of Organizational Behavior, Vol. 25, No. 5, pp. 641-665.

Rubin, M. and R. Richardson (1997), Microeconomics of the Shorter Working Week, Avebury, Feburary.

Sáenz-Royo, C. and V. Salas-Fumás (2013), "Learning to Learn and Productivity Growth: Evidence from a New Car-Assembly Plant," Omega, Vol. 41, No. 2, pp. 336-344.

Shapiro, M. D. (1986), "The Dynamic Demand for Capital and Labor," Quarterly Journal of Economics, Vol. 101, pp. 513-42. 
Shepard, E. and T. Clifton (2000), "Are Longer Hours Reducing Productivity in Manufacturing?," International Journal of Manpower, Vol. 21, No. 7, pp. 540-553.

Van Garderen, K. J., K. Lee and M. H. Pesaran (2000), "Cross-Sectional Aggregation of Non-linear Models," Journal of Econometrics, Vol. 95, No. 2, pp. 285-331.

Weiss, Andrew (1994), "Productivity Changes Without Formal Training," in Lynch, Lisa L. (eds.) Training and the Private Sector, Chicago: Chicago University Press.

Wright, T.P. (1936), "Factors Affecting the Cost of Airplanes," Journal of Aeronautical Sciences, Vol. 3, No. 4, pp. 122-128. 


\section{<Abstract in Korean >}

Dongyeol Lee*, Hyunjoon Lim**

1970년대 이후 대다수 선진국의 주당 평균 근로시간은 감소세를 지속해 왔다. 근로시간의 변동은 주로 "피로효과(fatigue effect)"와 “학습효과(learning effect)" 의 두 가지 상반된 경로를 통하여 시간당 생산성에 영향을 미친다. 근로시간의 연장은 근로자의 피로도를 가중시키는 데 반해 근로자의 업무 숙련도 및 기술의 향상을 가져올 수 있다. Hansen(1999)의 임계회귀법(threshold regression method)을 이용하여 콥-더글러스(Cobb-Douglas)와 트랜스로그(Translog) 생산 함수를 추정한 결과, 근로시간과 생산성의 상관관계에서 복수의 임계점(최대 4 개)이 존재하는 것으로 나타났다. 이는 근로시간 변동시 기존에 인식되어 온 피로 효과 외에도 학습효과가 작용한다는 본고의 가설을 지지하는 결과로 풀이된다.

본 분석결과는 최근의 근로시간 조정 논의와 관련하여 다음과 같은 몇 가지 시사점을 제공할 수 있다. 먼저 근로시간의 단축이 근로자들의 피로도를 낮추고 여가 활용을 가능케 함으로써 업무집중도를 높이고 생산성 제고에 기여하는 효과가 존재하는 반면, 근로자들의 업무숙련도 향상을 저해하고 기술습득을 지연 시킴으로써 생산성을 저하시키는 요인으로도 작용할 가능성이 있다. 다음으로 근로시간 조정의 전반적인 효과는 기존 근로시간 수준, 해당 산업의 특성, 기업 규모 등 다양한 요인에 따라 상이하게 나타날 수 있다.

* 한국은행 경제연구원 거시경제연구실 전문연구원

** 한국은행 경제연구원 거시경제연구실 전문연구원

연구내용은 집필자의 개인의견이며 한국은행의 공식견해와는 무관합니다. 따라서 본 논문의 내용을 보도 하거나 인용할 경우에는 집필자명을 반드시 명시하여 주시기 바랍니다. 